\title{
Change in global aerosol composition since preindustrial times
}

\author{
K. Tsigaridis ${ }^{1,{ }^{*}}$, M. Krol ${ }^{2}$, F. J. Dentener ${ }^{3}$, Y. Balkanski ${ }^{4}$, J. Lathière ${ }^{4}$, S. Metzger ${ }^{5}$, D. A. Hauglustaine ${ }^{4}$, and \\ M. Kanakidou ${ }^{1}$ \\ ${ }^{1}$ Environmental Chemical Processes Laboratory, Department of Chemistry, University of Crete, P.O. Box 2208, 71003, \\ Voutes, Heraklion, Greece \\ ${ }^{2}$ Netherlands Institute for Space Research, Utrecht, Netherlands and Wageningen University and Research Center, \\ Wageningen, Netherlands \\ ${ }^{3}$ European Commission, Joint Research Centre, Institute for Environment and Sustainability, Climate Change Unit, Ispra, \\ Italy \\ ${ }^{4}$ Laboratoire des Sciences du Climat et de l'Environnement, 91191 Gif-sur-Yvette Cedex, France \\ ${ }^{5}$ Max Planck Institute for Chemistry, Atmospheric Chemistry Division, Mainz, Germany \\ * now at: Laboratoire des Sciences du Climat et de l'Environnement, 91191 Gif-sur-Yvette Cedex, France
}

Received: 24 March 2006 - Published in Atmos. Chem. Phys. Discuss.: 28 June 2006

Revised: 16 October 2006 - Accepted: 6 November 2006 - Published: 10 November 2006

\begin{abstract}
To elucidate human induced changes of aerosol load and composition in the atmosphere, a coupled aerosol and gas-phase chemistry transport model of the troposphere and lower stratosphere has been used. The present 3-D modeling study focuses on aerosol chemical composition change since preindustrial times considering the secondary organic aerosol formation together with all other main aerosol components including nitrate. In particular, we evaluate non-seasalt sulfate (nss-SO $=$, ammonium $\left(\mathrm{NH}_{4}^{+}\right)$, nitrate $\left(\mathrm{NO}_{3}^{-}\right)$, black carbon (BC), sea-salt, dust, primary and secondary organics (POA and SOA) with a focus on the importance of secondary organic aerosols. Our calculations show that the aerosol optical depth (AOD) has increased by about $21 \%$ since preindustrial times. This enhancement of AOD is attributed to a rise in the atmospheric load of $\mathrm{BC}, \mathrm{nss}-\mathrm{SO}_{4}^{=}$, $\mathrm{NO}_{3}^{-}, \mathrm{POA}$ and SOA by factors of 3.3, 2.6, 2.7, 2.3 and 1.2 , respectively, whereas we assumed that the natural dust and sea-salt sources remained constant. The nowadays increase in carbonaceous aerosol loading is dampened by a $34-42 \%$ faster conversion of hydrophobic to hydrophilic carbonaceous aerosol leading to higher removal rates. These changes between the various aerosol components resulted in significant modifications of the aerosol chemical composition. The relative importance of the various aerosol components is critical for the aerosol climatic effect, since atmospheric aerosols behave differently when their chemical composition changes. According to this study, the aerosol composition changed significantly over the different conti-
\end{abstract}

Correspondence to: $\mathrm{M}$. Kanakidou

(mariak@chemistry.uoc.gr) nents and with height since preindustrial times. The presence of anthropogenically emitted primary particles in the atmosphere facilitates the condensation of the semi-volatile species that form SOA onto the aerosol phase, particularly in the boundary layer. The SOA burden that is dominated by the natural component has increased by $24 \%$ while its contribution to the AOD has increased by $11 \%$. The increase in oxidant levels and preexisting aerosol mass since preindustrial times is the reason of the burden change, since emissions have not changed significantly. The computed aerosol composition changes translate into about 2.5 times more water associated with non sea-salt aerosol. Additionally, aerosols contain 2.7 times more inorganic components nowadays than during the preindustrial times. We find that the increase in emissions of inorganic aerosol precursors is much larger than the corresponding aerosol increase, reflecting a non-linear atmospheric response.

\section{Introduction}

Atmospheric aerosols are important constituents of the global atmosphere. They have a direct effect on climate by scattering and/or absorbing solar radiation modifying the radiative balance of the atmosphere. They can act as condensation nuclei and cloud condensation nuclei, modify cloud properties and precipitation rates, thereby indirectly influencing the climate (IPCC, 2001). Their surface can also act as medium for heterogeneous reactions, modifying the chemical composition of both the gas and aerosol phases in the atmosphere (Tie et al., 2005).

Published by Copernicus GmbH on behalf of the European Geosciences Union. 
Aerosols contain numerous compounds, which may have various chemical and physical properties, in variable proportions and state of mixing (e.g. organic or inorganic, hydrophobic or hydrophilic). Over source areas the aerosol composition reflects that of the sources. Since the aerosol lifetime is of the order of a few days to a week, aerosols are transported, chemically transformed and affect areas far from where they have been formed. Moreover, organic aerosols (OA) significantly contribute to the total fine aerosol mass (Putaud et al., 2004). Important amounts of organic aerosols have also been observed in the middle troposphere (Hobbs et al., 1998; Huebert et al., 2004; Heald et al., 2005).

OA can be further separated in primary organic aerosols (POA), directly emitted in the atmosphere as aerosols, and secondary organic aerosols (SOA), which are formed after chemical reactions in the atmosphere. POA sources are mainly biomass burning and fossil fuel burning, although recent reports (Jaenicke, 2005; O'Dowd et al., 2004) suggest an important role for POA from various biogenic sources. Using recent information on SOA formation kinetics (Kanakidou et al., 2005a, and references therein), we recently evaluated that biogenically emitted volatile organic compounds (VOC) are the major precursors of SOA on a global scale (Tsigaridis and Kanakidou, 2003). Some of the biogenic VOC oxidation products are semi-volatile and are able to condense and produce new particles or increase the mass of the preexisting ones (Kanakidou et al., 2005a). Anthropogenic aromatic hydrocarbons can also produce SOA. Since POA and SOA have different sources they are also expected to have different chemical compositions and therefore different physicochemical and optical properties and impact on climate and environment.

The human driven emissions of gases and particles have drastically increased since preindustrial times (Van Aardenne et al., 2001). In parallel, humans affected the biogenic emissions via land use changes. Thus, both anthropogenic and biogenic emissions have changed since preindustrial era due to increased agricultural and industrial activities. These changes are reflected in the atmospheric chemical composition, i.e. the oxidant levels and the aerosol chemical composition and therefore, are expected to influence climate. Indeed, Stier et al. (2006) have made climate simulations for the years 1860-2100 and found that altering the chemical composition of aerosols together with their physical properties like mixing state and increased absorbance, affect the climate, especially when moving from the present time to future. The aim of the present work is to evaluate the modifications in the chemical composition of aerosols since preindustrial times due to the change in both the anthropogenic and biogenic emissions. We focus on the regional and global changes in the contribution of the various aerosol components that is expected to affect the properties of the atmospheric aerosols. The computation of associated climate impact is beyond the scope of the present study. Discussion follows on the chemical composition of the SOA components and the non-linear interactions of emissions and chemistry. The modeled spatial and temporal SOA composition variability and the factors that are controlling it are thoroughly presented and discussed.

\section{Model description}

To study the aerosol composition variability since preindustrial times, the global 3-dimensional chemistry transport model TM3 has been used (Houweling et al., 1998; Tsigaridis and Kanakidou, 2003; Tsigaridis et al., 2005, and references therein). A brief model description follows, emphasizing the differences from these earlier studies, as well as the elements that are important for the present discussion.

The model has a horizontal resolution of $3.75^{\circ} \times 5^{\circ}$ in latitude and longitude and 19 vertical hybrid layers from the surface to $10 \mathrm{hPa}$. Roughly, 5 layers are located in the boundary layer, 8 in the free troposphere and 6 in the stratosphere. The model is driven by ECMWF ERA15 re-analysis meteorological data-archive (Gibson et al., 1997; http://www.ecmwf.int/ research/era/ERA-15) updated every $6 \mathrm{~h}$. The ozone boundary conditions are based on TOMS data convoluted with climatological vertical ozone profiles as described in Lelieveld and Dentener (2000). A timestep of $90 \mathrm{~min}$ is applied for physics and $45 \mathrm{~min}$ for chemistry and aerosol production.

The model uses a modified version of the Carbon Bond chemical Mechanism version 4 (CBM-4; Gery et al., 1989) to simulate global atmospheric chemistry as described in detail by Houweling et al. (1998), together with sulphur and ammonia chemistry (Dentener et al., 1999; Jeuken et al., 2001). For the present study, reactions of terpenes and aromatics are affecting both gas-phase chemistry and aerosol production as described in detail in Tsigaridis and Kanakidou (2003). The $a$ - and $\beta$-pinenes represent two biogenic SOA precursor VOCs, while toluene and xylene represent two anthropogenically emitted aromatic compounds that form SOA. Biogenic emissions of monoterpenes and the $32 \%$ of ORVOC that are able to produce SOA (Griffin et al., 1999b) are distributed equally to $a$ - and $\beta$-pinene. SOA production from isoprene oxidation is taken into account using the simplified approach of $0.2 \%$ aerosol molar yield (Claeys et al., 2004). This approach does not make isoprene a substantial aerosol precursor and will be improved in future studies, based on Henze and Seinfeld (2006) recommendations.

\subsection{Present day simulation}

For the present day, we used a standard model simulation for the year 1990. The emissions adopted for the present and preindustrial simulations are shown in Table 1. Anthropogenic emissions vary annually based on EDGARHYDE 1.3 (Van Aardenne et al., 2001), as well as the emissions of $\mathrm{NO}_{\mathrm{x}}$ from soils and the biomass burning emissions of gases. The seasonality of biomass burning was kept 
the same in both simulations. Methane surface concentrations were scaled based on a polynomial fit of the latitudinal concentrations developed by Hein et al. (1997). The ORCHIDEE dynamic global vegetation model (Lathière et al., 2006) produced monthly varying biogenic emissions for the year 1990 (isoprene, monoterpenes and other reactive biogenic VOC) that are used in the TM3 model. DMS emissions are driven by the ERA-15 ECMWF $10 \mathrm{~m}$ wind speed and surface sea-water DMS concentrations compiled by Kettle et al. (1999). BC and POA emissions are based on the estimates of Ito and Penner (2005), which include both temporal and spatial variations for the present and preindustrial era. These emissions are similar with the average emissions given by Bond et al. (2004). The hydrophilic fractions of POA and $\mathrm{BC}$ emissions is assumed to be $80 \%$ and $50 \%$, respectively. Particulate nitrate and aerosol associated water (AAW) are computed online with EQSAM (Metzger et al., 2002). The AAW calculation is based only on the inorganic nss-sulfate, ammonium and nitrate components of the total aerosol mass. Therefore, neglecting the other aerosol components for the calculation of AAW affects neither the wet removal and the distribution of aerosols nor any other results of the present study, since AAW in the model is used only as a diagnostic variable. Moreover, the effect of aerosol size increase by water uptake on the extinction coefficients and thus in the AOD calculations is taken into account for all hydrophilic aerosol components based on a polynomial fit by Veefkind (1999) for sulfate aerosols as described in Tsigaridis et al. (2005).

Sea-salt and dust particles are taken into account for the present study. The daily emissions of these aerosol components come from the AEROCOM-B compilation for the year 2000 (http://nansen.ipsl.jussieu.fr/AEROCOM; Dentener et al., 2006). Following the AEROCOM recommendations we consider three modes for sea-salt aerosol (aitken, accumulation and coarse) and two for dust (accumulation and coarse) aerosol (Table 2).

\subsection{Preindustrial simulation}

For the preindustrial simulation, stratospheric ozone is forced based on the 1980 TOMS ozone column. This assumption though could underestimate preindustrial stratospheric ozone, since in 1980 the stratospheric ozone depletion and tropospheric ozone increase have been already initiated (Shindell and Faluvegi, 2002). For the preindustrial simulation, we used the same meteorology as in the present-day simulation, that of 1990 , but different emissions. Therefore, the computed changes since the preindustrial period are entirely driven by the change in emissions. Interestingly, the increase in emissions of inorganic aerosol precursors $\mathrm{SO}_{2}$ and dimethylsulfide (DMS; constant in both simulations), $\mathrm{NH}_{3}$ and $\mathrm{NO}_{\mathrm{x}}$ since the preindustrial period of about a factor of 3.4, 6 and 5, respectively, is much larger than the corresponding aerosol burden increase of nss-sulfate (factor of 2.6), ammonium (factor of 2.9) and nitrate (factor of 2.7), reflecting a
Table 1. Present (year 1990) and preindustrial (year 1860) emissions used by the model.

\begin{tabular}{|c|c|c|c|}
\hline & Present & Preindustrial & Units \\
\hline $\mathrm{NO}_{\mathrm{x}}$ & 45.0 & 9.2 & $\mathrm{Tg} \mathrm{Ny}^{-1}$ \\
\hline $\mathrm{CO}$ & 1051.8 & 218.5 & $\operatorname{Tg~}^{-1}$ \\
\hline $\mathrm{VOC}^{\mathrm{a}}$ & 250.9 & 96.5 & $\mathrm{Tg} \mathrm{Cy}^{-1}$ \\
\hline $\mathrm{CH}_{2} \mathrm{O}$ & 19.2 & 2.0 & $\operatorname{Tg} \mathrm{y}^{-1}$ \\
\hline Isoprene & 467.5 & 409.4 & $\mathrm{TgCy}^{-1}$ \\
\hline Monoterpenes & 120.8 & 126.4 & $\mathrm{TgCy}^{-1}$ \\
\hline ORVOC $^{b}$ & 221.0 & 207.4 & $\mathrm{Tg} \mathrm{Cy}^{-1}$ \\
\hline POA & 44.4 & 20.1 & $\operatorname{Tg} \mathrm{y}^{-1}$ \\
\hline $\mathrm{BC}$ & 7.5 & 2.1 & $\operatorname{Tg~}^{-1}$ \\
\hline Aromatic VOC & 14.3 & 0.0 & $\mathrm{TgCy}^{-1}$ \\
\hline DMS & 18.5 & 18.5 & $\operatorname{TgS} \mathrm{y}^{-1}$ \\
\hline Anthropogenic $\mathrm{SO}_{2}$ & 73.0 & 2.4 & $\operatorname{Tg} y^{-1}$ \\
\hline Volcanic $\mathrm{SO}_{2}$ & 9.2 & 9.2 & $\operatorname{Tg}_{y^{-1}}$ \\
\hline $\mathrm{NH}_{3}$ & 44.1 & 7.3 & $\operatorname{Tg~}^{-1}$ \\
\hline Sea-salt ${ }^{c}$ & 7804.2 & 7804.2 & $\operatorname{Tg} \mathrm{y}^{-1}$ \\
\hline Dust $^{c}$ & 1704.1 & 1704.1 & $\operatorname{Tg} y^{-1}$ \\
\hline
\end{tabular}

a: Excluding biogenic species line isoprene, monoterpenes and other reactive VOC (ORVOC).

$\mathrm{b}$ : The fraction of reactive biogenic VOC (excluding monoterpenes and isoprene) that is able to produce SOA is notated as ORVOC, while the non-SOA producing ORVOC (68\% of total ORVOC) are added to the VOC species.

c. Both preindustrial and present emissions are based on the year 2000 .

non-linear atmospheric response. Chemistry is a non-linear process since catalytic cycles and feedback mechanisms are involved, therefore the increase in the abundance of a species does not necessarily induces a proportional increase in its oxidation products, if they increase at all. As a consequence, linear processes, like emissions, coupled to chemistry will have a non-linear response (atmospheric burdens).

For the preindustrial simulation, the anthropogenic emissions are based on EDGAR-HYDE 1.3 for the year 1860 (Van Aardenne et al., 2001), as well as the emissions of $\mathrm{NO}_{\mathrm{x}}$ from soils and the biomass burning emissions of gases. Primary carbonaceous aerosol emissions are based on Ito and Penner (2005) for the year 1870. It has to be noted that most models assume that during the preindustrial period the biomass burning emissions are scaled to $10 \%$ of that of present day, while based on Ito and Penner (2005) this number is on global average $44 \%$, varying spatially. The biogenic emissions are calculated by Lathière et al. (2005) for the year 1850 and are based on present day climate forcing from CRU (Climate Research Unit, UK) with relative humidity corrected using ECMWF data, and a preindustrial $\mathrm{CO}_{2}$ atmospheric mixing ratio of $280 \mathrm{ppmv}$. Note that the present day high atmospheric $\mathrm{CO}_{2}$ levels enhance the biogenic VOC emissions (due to increased leaf expansion) counterbalancing 
Table 2. Sea-salt and dust aerosol log-normal mode properties.

\begin{tabular}{|c|c|c|c|c|c|c|}
\hline & \multicolumn{3}{|c|}{ Sea-salt } & \multicolumn{3}{|c|}{ Dust } \\
\hline & $\begin{array}{l}\text { Diameter } \\
(\mu \mathrm{m})\end{array}$ & Sigma & $\begin{array}{l}\text { Density } \\
\left(\mathrm{g} \mathrm{cm}^{-3}\right)\end{array}$ & $\begin{array}{l}\text { Diameter } \\
(\mu \mathrm{m})\end{array}$ & Sigma & $\begin{array}{l}\text { Density } \\
\left(\mathrm{g} \mathrm{cm}^{-3}\right)\end{array}$ \\
\hline Aitken & $0.01-0.1$ & 1.59 & 2.2 & - & - & - \\
\hline Accumulation & $0.1-1$ & 1.59 & 2.2 & $0.1-1$ & 1.59 & 2.5 \\
\hline Coarse & $1-20$ & 2.00 & 2.2 & $1-12$ & 2.00 & 2.5 \\
\hline
\end{tabular}

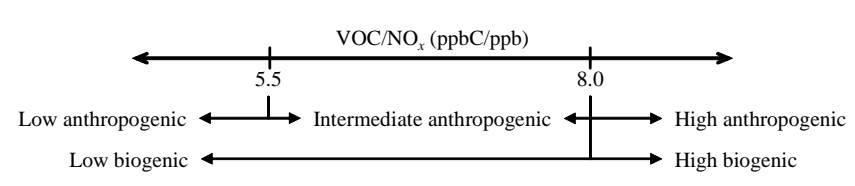

Fig. 1. $\mathrm{VOC} / \mathrm{NO}_{\mathrm{x}}$ regimes used in the SOA calculations. Anthropogenic: Song et al. (2005); biogenic: Presto et al. (2005).

the reduction of biogenic VOC emissions due to deforestation. This leads to a global increase of biogenic VOC emissions of $9 \%$, most of it due to isoprene; SOA precursor VOC (monoterpenes and ORVOC; see Table 1) have been increased by only $2 \%$. We assumed no changes of DMS seawater concentrations between the pre-industrial and present time. Dust and sea-salt natural emissions are the same for the pre-industrial and present day simulations, an assumption which is consistent with Menon et al. (2002) that indicate an increase of about $8 \%$ in sea-salt load since preindustrial era in their standard simulation.

\subsection{SOA parameterization}

The TM3 model includes coupled gas- and aerosol-phase calculations that include equilibrium chemistry of inorganic aerosol components and partitioning of semi-volatile gasphase compounds to the aerosol phase. Additionally, the heterogeneous reaction of $\mathrm{N}_{2} \mathrm{O}_{5}$ on inorganic aerosols and chemical transformation of hydrophobic primary carbonaceous aerosols to hydrophilic by reaction with ozone are included. This chemical aging process depends therefore on $\mathrm{O}_{3}$ levels and affects the removal of carbonaceous aerosols from the atmosphere, since hydrophilic aerosols are more efficiently scavenged from the atmosphere than hydrophobic ones. All aerosols are considered to be externally mixed. SOA formation is described using a two-product model approximation, which has been shown to be the simplest way to efficiently represent aerosol formation from both biogenic (Hoffmann et al., 1997) and aromatic VOC (Odum et al., 1997):

$\mathrm{VOC}+$ oxidant $\rightarrow a_{1} \mathrm{SOA}_{1}+a_{2} \mathrm{SOA}_{2}+$ high volatility products

Where $a_{i}$ is the mass-based production yield of the semivolatile lumped $\mathrm{SOA}$ product $\mathrm{SOA}_{i}$ that partitions between the gas and particulate phase with a partitioning coefficient $K_{i}$. The oxidants considered in the model for VOC oxidation are $\mathrm{O}_{3}, \mathrm{OH}$ and $\mathrm{NO}_{3}$ radicals. However, we assumed that in the case of biogenic hydrocarbons the only oxidant leading to SOA formation is $\mathrm{O}_{3}$, while for the aromatic VOC both $\mathrm{OH}$ radicals and $\mathrm{O}_{3}$ are initiating SOA production. For the biogenic VOC, partly due to the increased reactivity applied in order to accurately represent the mixture of monoterpenes and higher homologues by only $a$ - and $\beta$-pinene, ozonolysis consumes roughly $80 \%$ of this mixture. Further, the partitioning data reported by Presto et al. (2005) are for the ozonolysis of $a$-pinene. However, assuming that all oxidants can contribute to SOA formation, with the ozonolysis reported yields, only a $16 \%$ increase in global annual SOAb production is calculated, leading to a $29 \%$ increase to the corresponding burden. For aromatics, the ozonolysis of aromatics is very slow; indeed, more than $99 \%$ of aromatic species are being consumed by the reaction of $\mathrm{OH}$ radicals in the TM3 model. Therefore, the oxidation of aromatics by other oxidants than $\mathrm{OH}$ turns to be negligible source of anthropogenic SOA. The adopted parameterization, together with the related uncertainties in the calculations, has been described in detail earlier (Tsigaridis and Kanakidou, 2003). Although Tsigaridis and Kanakidou (2003) have shown that the oxidation of SOA components can increase the SOA production by about $20 \%$, in the present study the $\mathrm{SOA}_{i}$ components are assumed to be chemically inert, since the parameterization is based on overall yields of SOA formation from chamber experiments. More detailed information on the base scenario used in this study is described in Tsigaridis et al. (2005).

The lumped compounds $\mathrm{SOA}_{i}$ have different production coefficients $a_{i}$, different partitioning coefficients to the aerosol phase (high partitioning coefficient means that the compound preferably partitions on the aerosol phase and has lower vapor pressure) and different enthalpies of vaporization $\Delta H$ (the temperature dependence of the partitioning coefficients is linked to the $\Delta H$; high $\Delta H$ means stronger dependence of the vapor pressure on temperature; for details see Tsigaridis and Kanakidou, 2003).

In the present study, the above mentioned SOA formation mechanism has been improved in order to be able to calculate different products with different SOA formation yields 
Table 3. Properties of the SOA species used by the two product model for SOA formation.

\begin{tabular}{llllll}
\hline Name $^{1}$ & Parent VOC & $a_{i}$ (mass based) & $K_{p}\left(\mathrm{~m}^{3} \mu \mathrm{g}^{-1}\right)$ & $\Delta H\left(\mathrm{~kJ} \mathrm{~mol}^{-1}\right)$ & Reference $^{2}$ \\
\hline APINp1 & $a$-pinene & 0.125 & 0.088 & 72.9 & $\mathrm{G}$ \\
APINp2 & $a$-pinene & 0.102 & 0.0788 & 72.9 & $\mathrm{G}$ \\
APINp1N & $a$-pinene & 0.0138 & 0.0637 & 72.9 & $\mathrm{P}$ \\
APINp2N & $a$-pinene & 0.461 & 0.0026 & 72.9 & $\mathrm{P}$ \\
APINp1H & $a$-pinene & 0.192 & 0.0637 & 72.9 & $\mathrm{P}$ \\
APINp2H & $a$-pinene & 0.215 & 0.0026 & 72.9 & $\mathrm{P}$ \\
BPINp1 & $\beta$-pinene & 0.026 & 0.195 & 109 & $\mathrm{G}$ \\
BPINp2 & $\beta$-pinene & 0.485 & 0.003 & 72.9 & $\mathrm{G}$ \\
TOLp1 & toluene & 0.071 & 0.053 & 72.9 & $\mathrm{O}$ \\
TOLp2 & toluene & 0.138 & 0.0019 & 72.9 & $\mathrm{O}$ \\
XYLp1 & xylene & 0.038 & 0.042 & 72.9 & $\mathrm{O}$ \\
XYLp2 & xylene & 0.167 & 0.0014 & 72.9 & $\mathrm{O}$ \\
XYLp1N & xylene & 0.049 & 0.301 & 72.9 & $\mathrm{~S}$ \\
XYLp2N & xylene & 0.178 & 0.008 & 72.9 & $\mathrm{~S}$ \\
XYLp1H & xylene & 0.024 & 0.229 & 72.9 & $\mathrm{~S}$ \\
XYLp2H & xylene & 0.152 & 0.004 & 72.9 & $\mathrm{~S}$ \\
\hline
\end{tabular}

\footnotetext{
${ }^{1}$ Nomenclature of species was chosen as follows: First 3 or 4 capital letters denote the parent VOC. The letter "p", followed by the number 1 or 2 , denotes the product number. In case there is an additional letter " $\mathrm{N}$ " or "H", it denotes formation under low and high $\mathrm{VOC} / \mathrm{NO}_{x}$ ratio conditions, respectively. For the intermediate case of aromatic oxidation $\left(5.5<\mathrm{VOC} / \mathrm{NO}_{\mathrm{x}}<8\right.$ in ppbC/ppb; Song et al., 2005), the average parameters of high-to-low $\mathrm{VOC} / \mathrm{NO}_{\mathrm{x}}$ were used.

${ }^{2}$ G: Griffin et al. (1999a); O: Odum et al. (1997); P: Presto et al. (2005); S: Song et al. (2005).
}

depending on the $\mathrm{VOC} / \mathrm{NO}_{\mathrm{x}}$ ratio, as proposed by Presto et al. (2005) for $a$-pinene and Song et al. (2005) for xylene (Fig. 1). In order to simulate the $\mathrm{VOC} / \mathrm{NO}_{\mathrm{x}}$ dependence on SOA formation from $\beta$-pinene and toluene, their aerosol production capability $\left(a_{i}\right.$ and $\left.K_{i}\right)$ has been scaled based on the $a$-pinene and xylene SOA production dependence on $\mathrm{NO}_{\mathrm{x}}$. For example, the partitioning coefficient $K_{\text {BPINp1N }}$ used in the model ( $\beta$-pinene oxidation product in low $\mathrm{VOC} / \mathrm{NO}_{\mathrm{x}}$ regime; see Table 3 for nomenclature), is calculated as follows:

$$
K_{\mathrm{BPINp} 1 \mathrm{~N}}=K_{\mathrm{BPINp} 1} / K_{\mathrm{APINp} 1} \times K_{\mathrm{APINp} 1 \mathrm{~N}}
$$

These numbers can be found in Table 3 for the precursor VOCs considered in the present study. Including such a representation in the calculation of SOA formation reduces the chemical production of biogenic SOA by about $20 \%$ and increases the anthropogenic SOA by about the same percentage. This happens because the new biogenic SOA parameterization accounts for more volatile components produced at low $\mathrm{VOC} / \mathrm{NO}_{\mathrm{x}}$ environments, though in the anthropogenic SOA case the adopted yields from Song et al. (2005) are higher than the ones from Odum et al. (1997). Additionally, the product distribution differs substantially around the globe; high $\mathrm{VOC} / \mathrm{NO}_{\mathrm{x}}$ products are dominant above remote regions, while low $\mathrm{VOC} / \mathrm{NO}_{\mathrm{x}}$ products are more abundant above industrialized areas. Since the more volatile products are expected to have a different climatic impact compared to the less volatile products, due to different physical and chem- ical properties of the particles produced, we recommend that future SOA modeling studies include the $\mathrm{VOC} / \mathrm{NO}_{\mathrm{x}}$ dependence on the SOA production.

\subsection{Aerosol removal processes}

Dry deposition for all aerosol components is parameterized similarly to that of nss-sulfate, except for dust and sea-salt particles for which sedimentation has also been considered (Table 4). The in-cloud scavenging of dust, of the hydrophobic primary carbonaceous aerosols and of the $20 \%$ of SOA that is assumed hydrophobic (Chung and Seinfeld, 2002) is lower than that of nss-sulfate (due to their lower water affinity) whereas the below-cloud scavenging is kept the same (Seinfeld and Pandis, 1998). The other aerosol components are scavenged with the same efficiency as nss-sulfate. Number and mass distributions of sea-salt and dust are calculated every time step for each mode separately, assuming the lognormal distributions described in Table 2. The size distribution of sea-salt and dust affects their dry deposition rate since sedimentation that is negligible for small particles, dominates for large particle sizes, Wet removal (solubility to clouds and below-cloud scavenging) though is the same for all sizes but depends on its hydrophobic or hydrophilic character of the particles as explained earlier. 
Table 4. Percentage contribution of the removal processes for all aerosol components in the model. Sea-salt coarse fraction has larger size than the dust coarse fraction (Table 2).

\begin{tabular}{lllllll}
\hline & \multicolumn{3}{c}{ present } & \multicolumn{2}{c}{ preindustrial } \\
& wet & dry & sedimentation & wet & dry & sedimentation \\
\hline sulfate & $90.5 \%$ & $9.5 \%$ & $0.0 \%$ & $92.8 \%$ & $7.2 \%$ & $0.0 \%$ \\
ammonium & $81.7 \%$ & $18.3 \%$ & $0.0 \%$ & $87.3 \%$ & $12.7 \%$ & $0.0 \%$ \\
nitrate & $69.9 \%$ & $30.1 \%$ & $0.0 \%$ & $83.9 \%$ & $16.1 \%$ & $0.0 \%$ \\
SOA & $88.6 \%$ & $11.4 \%$ & $0.0 \%$ & $90.9 \%$ & $9.1 \%$ & $0.0 \%$ \\
POA & $74.9 \%$ & $25.1 \%$ & $0.0 \%$ & $73.6 \%$ & $26.4 \%$ & $0.0 \%$ \\
BC & $76.3 \%$ & $23.7 \%$ & $0.0 \%$ & $75.0 \%$ & $25.0 \%$ & $0.0 \%$ \\
sea-salt (fine) & $56.2 \%$ & $43.7 \%$ & $0.1 \%$ & $56.2 \%$ & $43.7 \%$ & $0.1 \%$ \\
sea-salt (accum) & $55.0 \%$ & $43.0 \%$ & $2.0 \%$ & $55.0 \%$ & $43.0 \%$ & $2.0 \%$ \\
sea-salt (coarse) & $8.9 \%$ & $9.8 \%$ & $81.3 \%$ & $8.9 \%$ & $9.8 \%$ & $81.3 \%$ \\
dust (accum) & $47.8 \%$ & $44.6 \%$ & $7.6 \%$ & $47.8 \%$ & $44.6 \%$ & $7.6 \%$ \\
dust (coarse) & $8.7 \%$ & $12.1 \%$ & $79.2 \%$ & $8.7 \%$ & $12.1 \%$ & $79.2 \%$ \\
\hline
\end{tabular}

\section{Results}

\subsection{Oxidant fields}

The change in the levels of oxidants $\left(\mathrm{O}_{3}, \mathrm{NO}_{3}, \mathrm{H}_{2} \mathrm{O}_{2}\right.$ and $\mathrm{OH}$ ) is important for the degradation of VOC and sulfur dioxide, and therefore for the formation of secondary aerosols. $\mathrm{H}_{2} \mathrm{O}_{2}$ and $\mathrm{OH}$ are important for the formation of $\mathrm{SO}_{4}^{=}$, whereas $\mathrm{O}_{3}$ is the dominant oxidant responsible for the SOA formation. Limited information is available from measurements that give an indication on the levels of oxidants during the preindustrial period. Based on our model calculations, the mean boundary layer ozone concentration has increased by more than $74 \%$ since preindustrial times, while the corresponding $\mathrm{NO}_{\mathrm{x}}$ burden has been increased by more than a factor of 4 . The increase in the boundary layer ozone concentration resulted in a net decrease in biogenic VOC concentrations by $42 \%$ for the case of isoprene and $59 \%$ for monoterpenes. The global mean $\mathrm{OH}$ radical concentration also changed since preindustrial era, resulting in a $5 \%$ increase of the tropospheric methane lifetime. The change in the oxidizing capacity of the atmosphere led to a longer lifetime of $\mathrm{SO}_{2}$ due to chemical reactions that produce sulfate particles, combined with an increase in its atmospheric load.

Comparison with the few existing measurements during the preindustrial period (Volz and Kley, 1988; Anfossi et al., 1991; Sandroni et al., 1992; Marenco et al., 1994; Sandroni and Anfossi, 1994; Pavelin et al., 1999) indicates that the model may overestimate ozone concentrations (within a factor of two and in some cases above a factor of 3), with only 3 occasions (over wintertime Japan) of calculated $\mathrm{O}_{3}$ concentration above $30 \mathrm{ppbv}$. These high $\mathrm{O}_{3}$ levels are mainly associated with strong stratospheric influx of ozone in the troposphere in the northern hemisphere during the winter and spring periods. The strong stratospheric influx of $\mathrm{O}_{3}$ is a feature common to global models (Pavelin et al., 1999).
Moreover, it has to be noted that the preindustrial ozone measurements are highly uncertain, since the Schönbein method used at the end of the nineteenth century suffers from significant interference from several sources (Pavelin et al., 1999). With regard to $\mathrm{H}_{2} \mathrm{O}_{2}$ levels, the observed increase of $50 \%$ in Greenland since preindustrial times (Sigg and Neftel, 1991) is consistent with our model calculated increase of $48 \%$.

\subsection{Aerosol burden}

Some indication on the changes in the levels of aerosol constituents since preindustrial period is provided by the ice core measurements. These measurements (Greenland ice core; Mayewski et al., 1986) show an increase in nsssulfate and nitrate concentration by a factor of 2.8 (from 30 to $84 \mu \mathrm{g} \mathrm{kg}^{-1}$ ) and 2.1 (from 55 to $115 \mu \mathrm{g} \mathrm{kg}^{-1}$ ), respectively, since preindustrial times that is lower than the calculated increase by the model (3.9 and 6.4, respectively). Although both measurements and model results are associated with large uncertainties, they indicate that significant changes have occurred both in oxidant levels and in aerosol composition since preindustrial era. In addition, as discussed earlier, the turnover time of the hydrophobic to hydrophilic carbonaceous aerosol depends on oxidant levels. According to our model online calculations, this turnover time has been reduced due to the increase in $\mathrm{O}_{3}$ levels, from 1.7 days (for $\mathrm{POA}$ ) and 1.8 days (for BC) during preindustrial times to 1.1 and 1.0 days, respectively.

Our model calculations suggest that the total annual average aerosol mass in the model domain has increased since preindustrial times from $26.8 \mathrm{Tg}$ to $28.9 \mathrm{Tg}$ (Table 5). This increase is attributed to all aerosol components except dust and sea-salt, which were kept constant at present-day levels. Excluding these natural aerosol components, the calculated aerosol mass has increased from $2.7 \mathrm{Tg}$ to $4.8 \mathrm{Tg}$. Note that our model does not account for the mixing of aerosols 
Table 5. Global annual average aerosol burden for the present and preindustrial simulations and comparison with the literature. All units are Tg.

\begin{tabular}{lllll}
\hline & \multicolumn{2}{c}{ This work } & \multicolumn{2}{c}{ Previous works } \\
Aerosol type (units) & Present & Preind & Present & $0.10-0.58^{2}$ \\
\hline Nss-sulfate & 1.05 & 0.40 & $0.29-2.55^{1}$ & $0.12^{3}$ \\
Ammonium & 0.35 & 0.12 & $0.33-0.54^{3, \mathrm{~b}}$ & $0.10-0.18^{5}$ \\
Nitrate & 0.31 & 0.12 & $0.04-0.63^{4}$ & \\
MSA & 0.22 & 0.27 & & $0.06-0.6^{7}$ \\
SOAb & 0.75 & 0.64 & $0.01-1.6^{6}$ & \\
SOAa & 0.05 & 0.00 & $<0.01-0.03^{8}$ & $0.096-0.11^{10}$ \\
POA & 0.60 & 0.27 & $0.77-1.48^{9}$ & $0.03-0.17^{12}$ \\
total OA & 1.40 & 0.91 & $0.24-2.21^{11}$ & $0.011-0.02^{10}$ \\
BC & 0.12 & 0.03 & $0.11-0.29^{13}$ & $0.96^{15}$ \\
Sea-salt & 4.45 & 4.45 & $0.97-13.21^{14}$ & \\
Dust & 19.60 & 19.60 & $7.9-35.9^{16, \mathrm{c}}$ & \\
\hline
\end{tabular}

1 AEROCOMa ; Stier et al. (2005); Adams et al. (2001); Tie et al. (2005); Rotstayn and Lohmann (2002); Koch et al. (2003); Kirkevåg and Iversen (2002); Rasch et al. (2000); Chin et al. (2000); Koch (2001); Barth et al. (2000); Kiehl et al. (2000); Boucher and Pham (2002); Chuang et al. (2002); Derwent et al. (2003); Menon et al. (2002); Liao and Seinfeld (2005); TM5 ${ }^{\text {b }}$

2 Adams et al. (2001); Boucher and Pham (2002); Kiehl et al. (2000); Menon et al. (2002); Liao and Seinfeld (2005)

3 Adams et al. (2001)

${ }^{4}$ Adams et al. (2001); Derwent et al. (2003); Liao and Seinfeld (2005); TM5

5 Adams et al. (2001); Liao and Seinfeld (2005)

6 Tsigaridis and Kanakidou (2003); Kanakidou et al. (2000); Chung and Seinfeld (2002); Griffin et al. (1999b); Derwent et al. (2003); Liao and Seinfeld (2005)

${ }^{7}$ Kanakidou et al. (2000); Chung and Seinfeld (2002); Liao and Seinfeld (2005)

8 Tsigaridis and Kanakidou (2003)

9 AEROCOM; Stier et al. (2005); Chung and Seinfeld (2002); Koch (2001); Liao and Seinfeld (2005); TM5

10 Chung and Seinfeld (2002); Liao and Seinfeld (2005)

11 Tie et al. (2005); Reddy and Boucher (2004); Chuang et al. (2002); Menon et al. (2002); Chung and Seinfeld (2002)

12 Menon et al. (2002); Chung and Seinfeld (2002)

13 AEROCOM; Stier et al. (2005); Tie et al. (2005); Kirkevåg and Iversen (2002); Koch (2001); Chung and Seinfeld (2002); Cooke and Wilson (1996); Liousse et al. (1996); Chuang et al. (2002); Liao and Seinfeld (2005); TM5

14 AEROCOM; Stier et al. (2005); Guelle et al. (2001); Liao et al. (2004); Tie et al. (2005); Chuang et al. (2002); Menon et al. (2002); TM5

15 Menon et al. (2002)

16 AEROCOM; Stier et al. (2005); Ginoux et al. (2001); Liao et al. (2004); Tie et al. (2005); Grini et al. (2005); Miller et al. (2004); Luo et al. (2003); Zender et al. (2003); Chuang et al. (2002); TM5

a AEROCOM: Median value of all models from the AEROCOM A intercomparison.

b TM5: Krol et al., The European aerosol budget, Manuscript in preparation; Kanakidou et al. (2005b).

${ }^{\mathrm{c}}$ Excluding the Chuang et al. (2002) and Ginoux et al. (2001) burden of more than $30 \mathrm{Tg}$, the range is 7.9-19.5 Tg.

that could alter the hygroscopicity and the removal of dust particles, a property that may have changed since preindustrial era (Kanakidou et al., 2005b). Nss-sulfate, nitrate and black carbon (BC) aerosol have strong anthropogenic sources, since they are either chemically produced by anthropogenically emitted precursor compounds $\left(\mathrm{SO}_{2}\right.$ and $\mathrm{NO}_{\mathrm{x}}$ for nss-sulfate and nitrate, respectively) or are directly emitted in the particulate phase (BC). Organic aerosols have also a strong primary anthropogenic source but are additionally produced by chemical transformation of biogenic and anthropogenic VOC (Tsigaridis and Kanakidou, 2003; Kanakidou et al., 2005a). This secondary source is calculated to increase from $12.8 \mathrm{Tg} \mathrm{y}^{-1}$ during preindustrial times to $19.3 \mathrm{Tg}^{-1}$ at present. Anthropogenic aromatic VOC oxidation and consequent aerosol production is responsible for $30 \%$ of this increase.

A comparison of the modeled present day results with measurements for $\mathrm{OA}, \mathrm{BC}$, sea-salt and dust is shown in Fig. 2. Organic aerosols are mostly underestimated by the model (on average by a factor of 2), while BC compares better with measurements. The model generally overestimates the sea-salt measurements below $2 \mu \mathrm{g} \mathrm{m}^{-3}$ by more than a factor of two, while the model simulates better the highest concentrations. The comparison with sea-salt measurements shows a better agreement in the Pacific Ocean, where model results are within a factor of 2 with observations at most 
OA

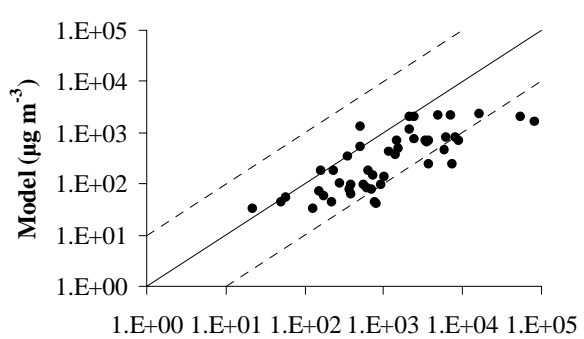

Measurements $\left(\mu \mathrm{g} \mathrm{m}^{-3}\right)$

Sea-salt

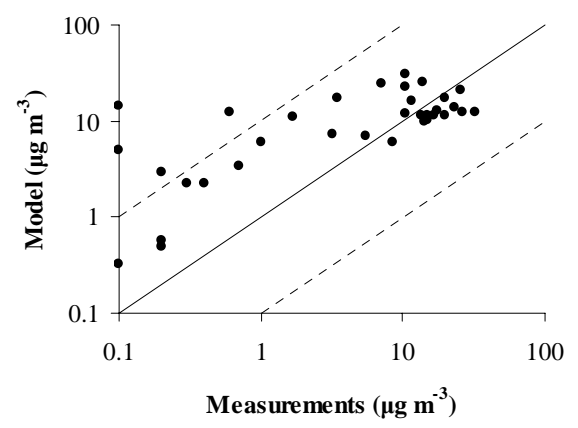

BC

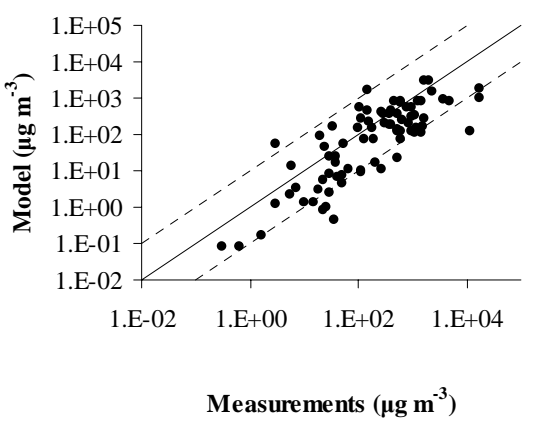

Dust

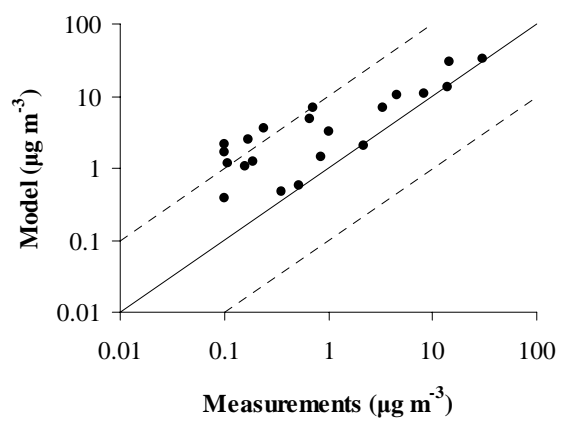

Fig. 2. Measured vs. modeled OA (top-left), BC (top-right), sea-salt (bottom-left) and dust (bottom-right) values for the present day. The solid line denotes the 1:1 ratio and the dashed lines the 1:10 and 10:1 ratios, respectively. Dust and sea-salt measurements are annual means from the European measurement network EMEP (http://www.emep.int), the North-American measurement network IMPROVE (http://vista.cira. colostate.edu/improve) and measurements compiled by the Global Atmosphere Watch (GAW) program (http://wdca.jrc.it). Carbonaceous aerosol measurements are those used in Tsigaridis and Kanakidou (2003).

measuring stations. From a total of 37 stations used in the comparison, only 4 of them are overestimated by more than a factor of 10 . Note however that the modeled mass concentration of sea-salt is totally determined by its very short-lived coarse fraction, a fact that severely hampers a comparison with measurements. For dust, the model agrees surprisingly well with the highest concentration levels, which mostly affect the global dust burden, and overestimates mainly those concentrations that are below $1 \mu \mathrm{g} \mathrm{m}^{-3}$. One station where the model overestimates the dust values by more than a factor of 10 is in the southern Atlantic Ocean (Yate, New Caledonia), with the others being in the Pacific. This indicates some deficiencies in the representation of long range transport and/or removal of dust in the model.

When comparing with other model results (Table 5), our simulations simulate well the sulfate burden and tend to lie close to the lowest values of global aerosol load for ammonium. The published values of atmospheric loads of POA and $\mathrm{BC}$ vary by more than a factor of 3 , with the results presented here being at the lower edge of those ranges for OA. BC agrees much better with the measured concentrations around the globe. This could be attributed either to (i) very efficient wet deposition (lifetime due to wet removal of 6.0 and 6.3 days for POA and BC, respectively at present), or to (ii) fast turnover time of the hydrophobic to hydrophilic carbonaceous aerosols (1.1 and 1.0 days for hydrophobic POA and $\mathrm{BC}$ respectively), or to (iii) the adopted $\mathrm{POA}$ and $\mathrm{BC}$ emissions that are generally lower than in other models (Textor et al., 2005) as discussed in Sect. 2. SOA burdens are within the range of previous studies. The sea-salt and dust global burdens lie within the range of previous published model estimates.

Ammonium is also lower than other models. Since ammonium, sulfate and nitrate are in thermodynamic equilibrium, the concentrations of nitrate depend on the availability of ammonium, which in turn is controlled by the amount of sulfate present since ammonium is preferably neutralizing sulfuric acid in the atmosphere and only the remaining ammonium is controlling the $\mathrm{HNO}_{3} / \mathrm{NO}_{3}^{-}$equilibrium. This nicely explains the differences between Adams et al. (2001) results and our model calculations. Adams et al. (2001) global ammonium burden is about $70 \%$ more than in our model, in 
parallel their nss-sulfate burden lies to the upper values of the published range and is more than 2 times higher than our results, however somewhat surprisingly for nitrate aerosol the two models are in closer agreement (within 20\%).

Among the studies reported in Table 5, only Liao and Seinfeld (2005) consider all major aerosols including SOA as in the present study. The preindustrial sulfate burden in Liao and Seinfeld (2005) is about 30\% higher than in our simulation, reflecting their adopted larger increase in $\mathrm{SO}_{2}$ emissions. In addition, nitrate aerosols in Liao and Seinfeld (2005) are 50\% more abundant than in our study, although the $\mathrm{NO}_{\mathrm{x}}$ emissions are similar, possibly reflecting the differences in the adopted ammonia emissions between the two studies, in both the preindustrial and present atmospheres. Differences in emissions of POA and BC are also reflected in the burdens of these aerosol components in both studies. Furthermore, in the present study biogenic SOA is more than double the calculated by Liao and Seinfeld (2005). This difference is attributed to the condensation of semi-volatile compounds also on inorganic aerosol components, and the consideration of anthropogenic SOA in the present work.

\subsection{Aerosol composition}

Figure 3 shows the computed relative contribution of the various aerosol components to the total aerosol burden for the present and the preindustrial atmospheres. Anthropogenic emissions have increased the nss-sulfate, nitrate, ammonium, $\mathrm{POA}$ and $\mathrm{BC}$ component of aerosols, resulting in a lower contribution of the natural components dust, sea-salt and MSA. SOA from biogenic VOC oxidation (SOAb) has increased its boundary layer load as a result of both higher oxidant (mainly $\mathrm{O}_{3}$ ) and pre-existing aerosol levels that enhance SOA production (chemical production and condensation). The increase of inorganic aerosol components in the total aerosol mass leads to more acidic and hygroscopic aerosols, due to the disproportional increase of the sum of nss-sulfate and nitrate relative to ammonium constituents.

Another important constituent of atmospheric particulate matter is the aerosol associated water (AAW), since it affects the chemical composition, size and optical properties of aerosols. Note that carbonaceous aerosols, sea-salt and dust are not taken into account in the calculation since they are not included in the EQSAM scheme used in the present study. In particular, the high variability and uncertainty in the organic aerosol hygroscopic behavior (Kanakidou et al., 2005a) is the limiting factor for the consideration of organics in the computations of the AAW. This will not affect the results strongly, since at low relative humidity organic aerosols are expected to be responsible for about $20 \%$ of the total AAW, while at high relative humidity their contribution becomes much less important (Kanakidou et al., 2005a). AAW contribution to the total aerosol mass has increased by a factor of 2.5 since preindustrial times, because the hygroscopicity of aerosols has increased due to human activities. This in-
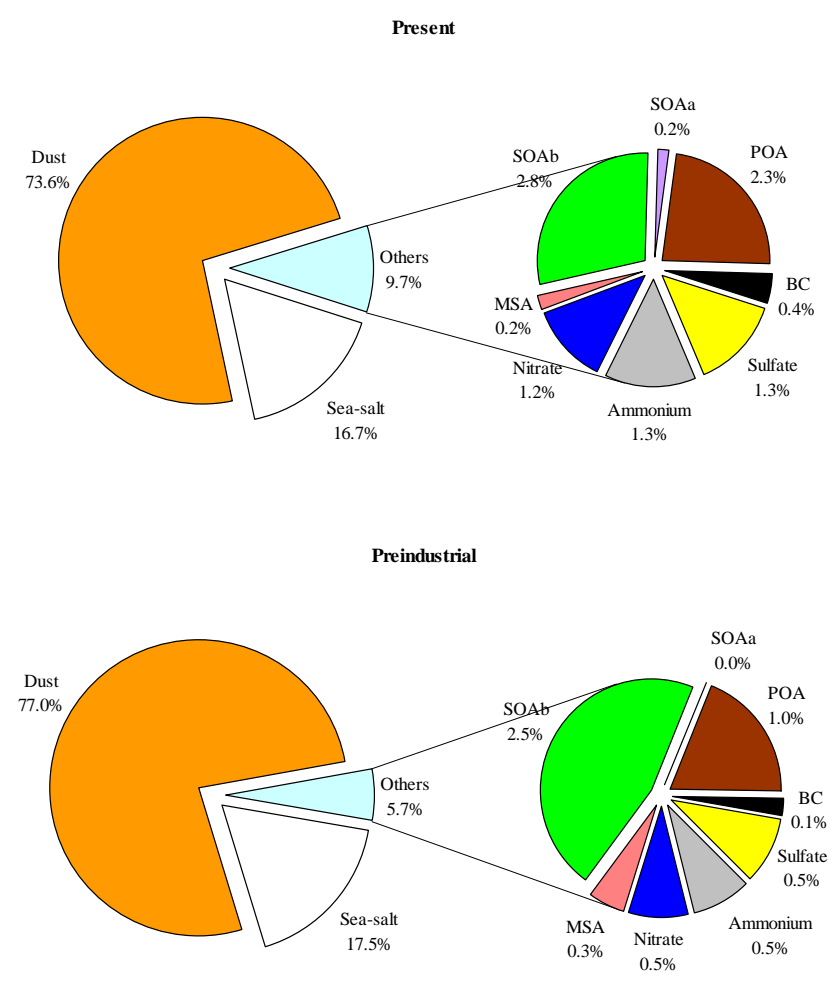

Fig. 3. Relative contribution of aerosol components to the total aerosol burden for the present (top) and preindustrial atmospheres (bottom) based on the model calculations. The total aerosol burden is $28.9 \mathrm{Tg}$ and $26.8 \mathrm{Tg}$, respectively.

crease can be explained by the general increase of inorganic constituent levels associated with more acidic aerosols. For the present day the model calculates more AAW than the total dry aerosol mass for most of the industrialized regions of the world (northeastern U.S., Europe, southeast China and Japan) where it has drastically increased since preindustrial times (Fig. 4).

With regard to the carbonaceous component of the aerosols, the BC and POA contributions to the total aerosol mass have increased by a factor of 3.3 and 2.3 , respectively, due to an increase of their emissions since preindustrial times. Present day OA (POA+SOA) can account for up to $90 \%$ of the total particulate matter (Fig. 4). During the preindustrial period the areas where $\mathrm{OA}$ is calculated to be the major component ( $>50 \%$ ) of the dry total particulate matter, are larger than at the present day. In contrast, BC contribution to dry total aerosol mass has increased since the preindustrial period from 0.1 to $0.4 \%$ (Fig. 4). BC has about 50 times higher emissions from fossil fuel burning and more than doubled open vegetation and biofuel burning emissions since preindustrial times. POA emissions from fossil fuel burning also increased by more than a factor of 30 and the emissions from open vegetation and biofuel burning have doubled. Additionally, an important part of OA comes from the oxidation of VOC. This secondary source is mainly 


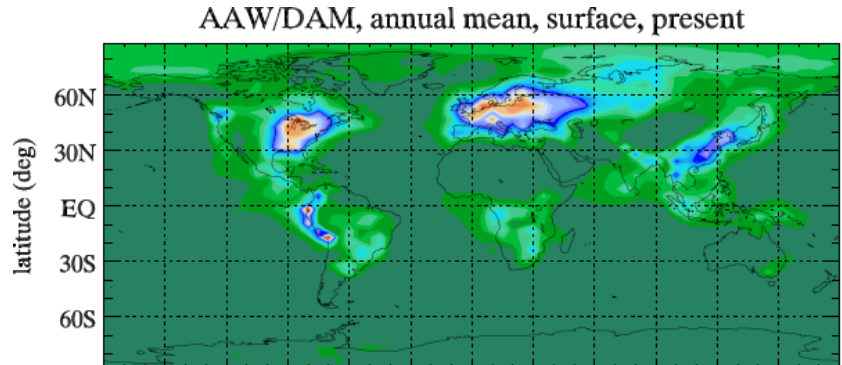

180W 150W 120W 90W 60W 30W 0E 30E 60E 90E 120E 150E 180E
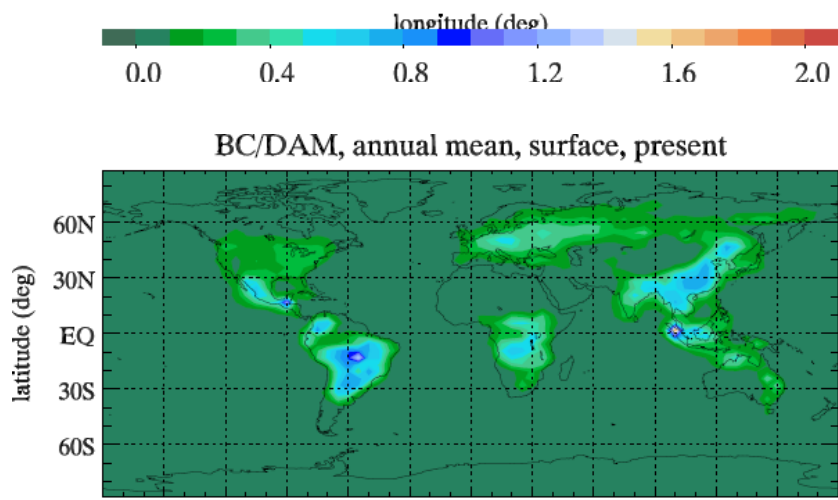

180W 150W 120W 90W 60W 30W $0 \mathrm{E}$ 30E $60 \mathrm{E}$ 90E $120 \mathrm{E}$ 150E $180 \mathrm{E}$

$\begin{array}{llllll}0.00 & 0.04 & 0.08 & 0.12 & 0.16 & 0.20\end{array}$

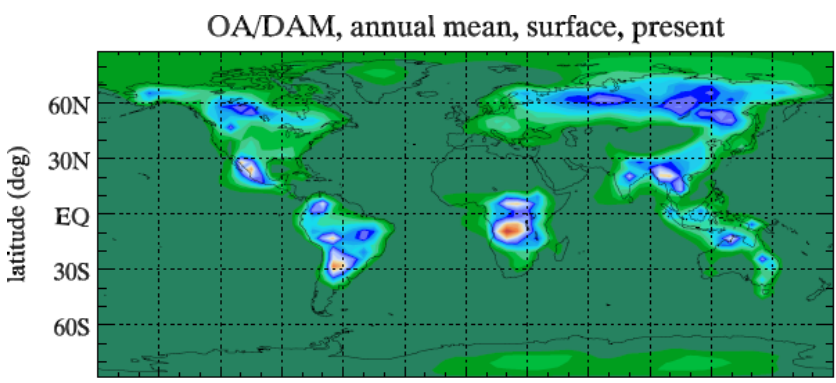

180W150W120W 90W 60W 30W 0E 30E 60E 90E 120E 150E 180E

$\begin{array}{llllll}0.00 & 0.16 & 0.32 & 0.48 & 0.64 & 0.80\end{array}$

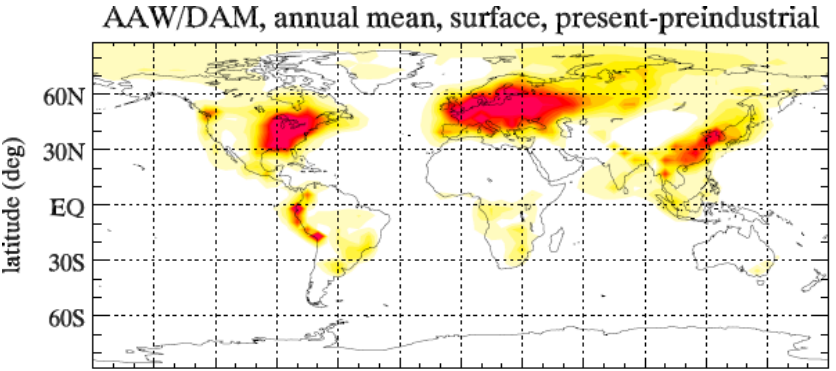

180W 150W120W 90W 60W 30W 0E 30E 60E 90E 120E 150E 180E
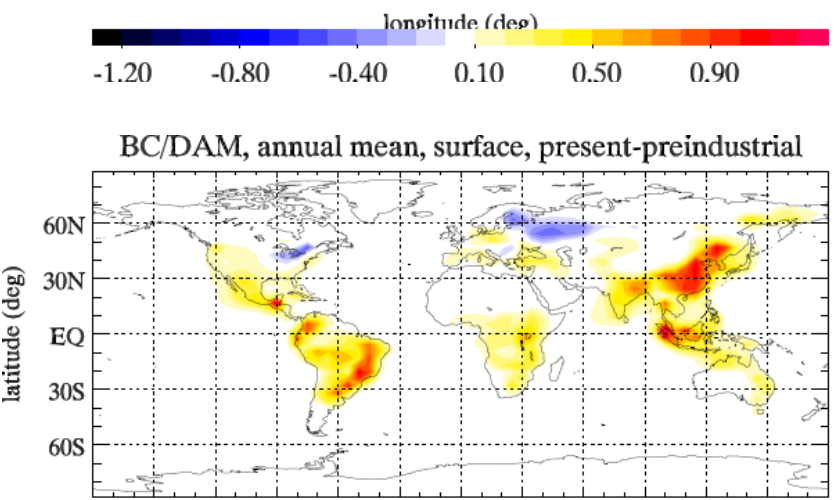

180W 150W 120W 90W 60W 30W 0E 30E 60E 90E 120E 150E 180E Ionoitude (deg)

$\begin{array}{llllll}-0.060 & -0.040 & -0.020 & 0.005 & 0.025 & 0.045\end{array}$

OA/DAM, annual mean, surface, present-preindustrial

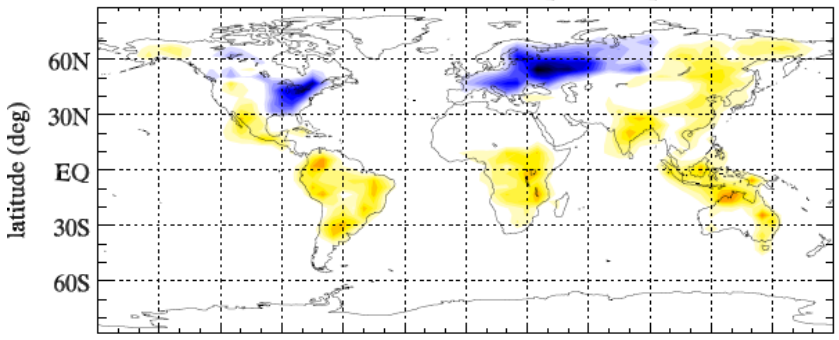

180W 150W 120W 90W 60W 30W 0E 30E 60E 90E 120E 150E 180E Ionoitude (deg)

$\begin{array}{llllll}-0.36 & -0.24 & -0.12 & 0.03 & 0.15 & 0.27\end{array}$

Fig. 4. Annual mean aerosol component to dry aerosol mass (DAM) surface ratio for the present (left panels) and the corresponding difference from the preindustrial (right panels) simulation. Aerosol components are AAW (top panels), BC (medium panels) and OA (bottom panels).

biogenic. Due to the small increase of SOA VOC precursors, the increase in SOA load is due to additional production which can be attributed mainly to the $\mathrm{O}_{3}$ increase since preindustrial times, and the increase of pre-existing aerosol mass, factors that together with temperature control SOA formation in the atmosphere (Tsigaridis and Kanakidou, 2003). The regional chemical composition of OA has changed strongly in the tropical biomass burning regions, India and Asia from the preindustrial era to present day, reflecting the disproportional change of SOA/OA ratios (Fig. 5).

\subsection{SOA chemical composition and controlling factors}

In addition to the changes in the contribution of SOA to the total OA mass, the chemical speciation of SOA is also expected to have changed since preindustrial times. Changes in the relative contribution of these species to the total SOA mass are expected to alter the aerosol optical properties and their ability to act as condensation nuclei and cloud condensation nuclei, having thus a major impact on climate. For instance, it is expected that by increasing $\mathrm{NO}_{\mathrm{x}}$ levels in the atmosphere, SOA will contain more of the high volatility species as well as organic nitrate species. The overall effect 


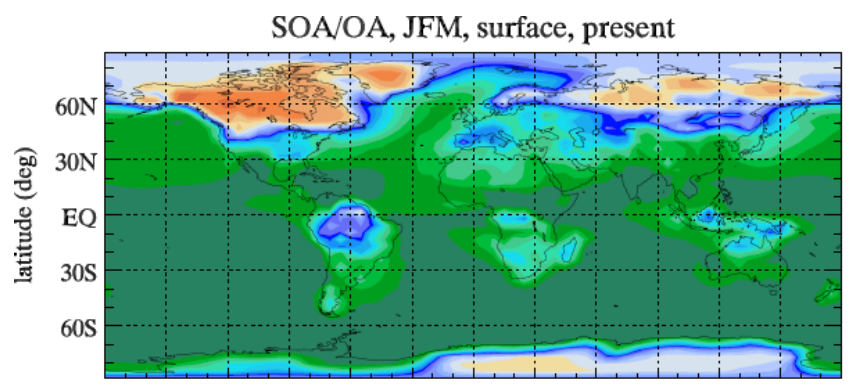

180W150W120W 90W 60W 30W $0 \mathrm{E} \quad 30 \mathrm{E} \quad 60 \mathrm{E} \quad 90 \mathrm{E} \quad 120 \mathrm{E} \quad 150 \mathrm{E} \quad 180 \mathrm{E}$ lonoitude(deo)

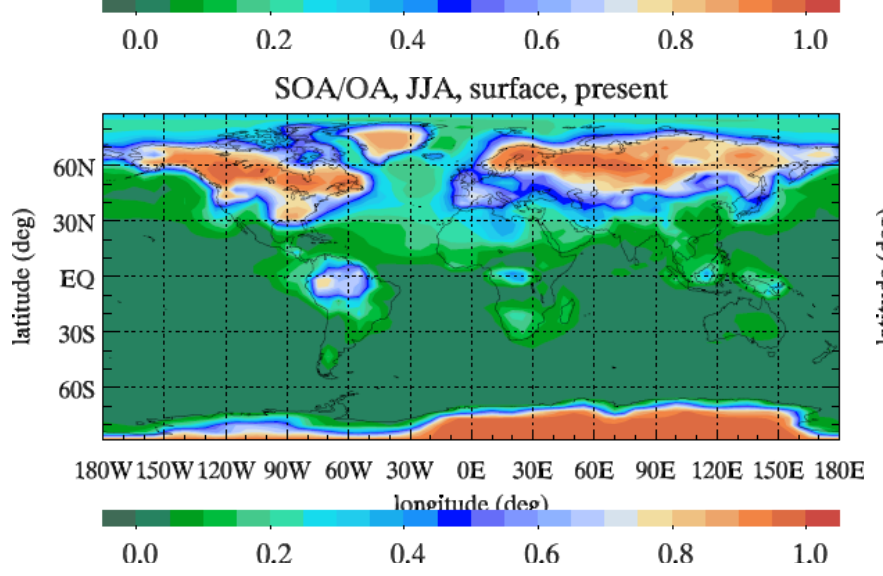

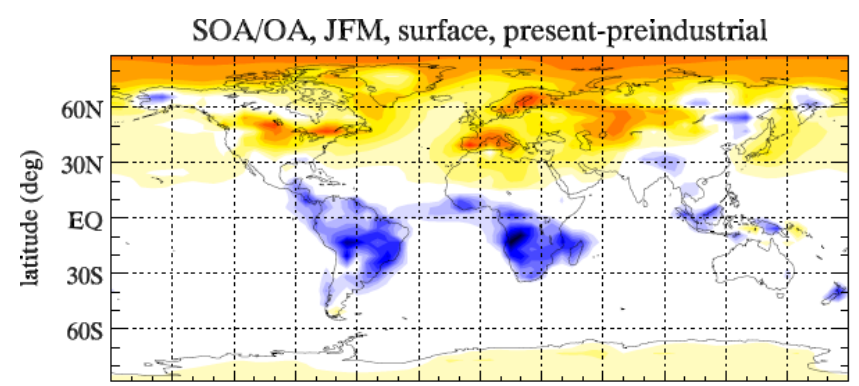

180W150W120W 90W 60W 30W $0 \mathrm{E} \quad 30 \mathrm{E} \quad 60 \mathrm{E} \quad 90 \mathrm{E} \quad 120 \mathrm{E} \quad 150 \mathrm{E}$ 180E lonoitude (deo)
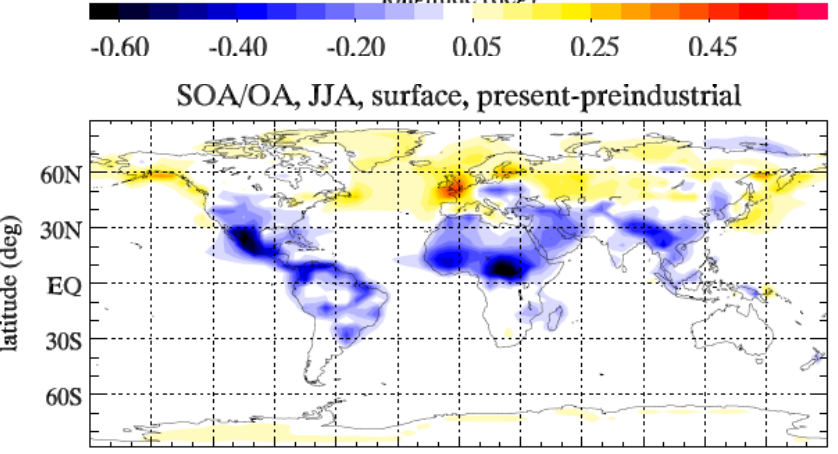

180W150W120W 90W 60W 30W $0 \mathrm{E} \quad 30 \mathrm{E} \quad 60 \mathrm{E} \quad 90 \mathrm{E} \quad 120 \mathrm{E} \quad 150 \mathrm{E}$ 180E

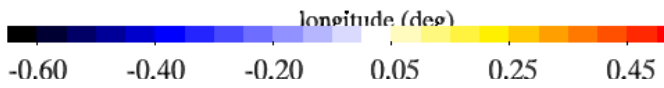

Fig. 5. SOA to OA mass surface ratio for winter (top panels) and summer (bottom panels) for the present (left panels) and the corresponding difference from the preindustrial (right panels) simulation.

is therefore expected to be an increase in the volatility of the aerosol and a decrease of the hygroscopicity (Presto et al., 2005). Note that higher volatility SOA species tend to condense at lower temperatures and thus at higher altitudes in the troposphere. It is therefore expected that the increase in $\mathrm{NO}_{\mathrm{x}}$ levels since preindustrial period will partially shift particle formation toward colder areas. However, this effect is counterbalanced by the increasing primary particles that enhance SOA formation in the boundary layer as further discussed. Indeed, the SOA species produced over low $\mathrm{VOC} / \mathrm{NO}_{\mathrm{x}}$ ratio areas contribute to $72 \%$ to the total SOA mass at present time, in contrast to the preindustrial region that this contribution was $48 \%$ (in the boundary layer the contributions are $50 \%$ and $7 \%$, respectively). The changes in the chemical composition of the SOA component are investigated in this section by the mean of the calculated changes in the lumped SOA species taken into account in our model.

\subsubsection{Changes at the surface}

In order to investigate the spatial change in the chemical composition of SOA since preindustrial times, we calculated for each one of the SOA species the spatial variation of the partitioning (Sect. 2) between the aerosol and the gas phases as the ratio of aerosol phase concentration to its total (aerosol and gas-phase) concentration. Figure 6 shows the ratios during July at the surface for two SOA species with distinct volatility and thus different properties and possible climatic impact (BPINp2H: relatively high volatility, expected to be mostly in the gas phase at surface; BPINp1H: relatively low volatility, expected to be mostly in the aerosol phase at surface; for naming of the species, see footnote of Table 3). In our model, BPINp1H has the highest partitioning coefficient (lowest vapor pressure) and additionally has a high enthalpy of vaporization (strong temperature dependence). This explains why it has the highest aerosol-phase to total mass ratio of all the model biogenic SOA species at the surface. In atmospheric samples this species could be linked to the less volatile among the semi-volatile compounds. On the contrary, the smallest partitioning coefficient from all SOA compounds (highest vapor pressure) has been attributed to the BPINp2H, thus this SOA species could correspond to the more volatile among the semi-volatile compounds found in atmospheric samples. The other semi-volatile compounds of the two product model produced from $\beta$-pinene oxidation are less abundant, while these produced from the $a$-pinene oxidation chain represent intermediate volatility for semivolatile compounds found in atmospheric samples.

BPINp2H is mostly in the gas-phase at the earth's surface, even over areas with high aerosol loads. This is most 


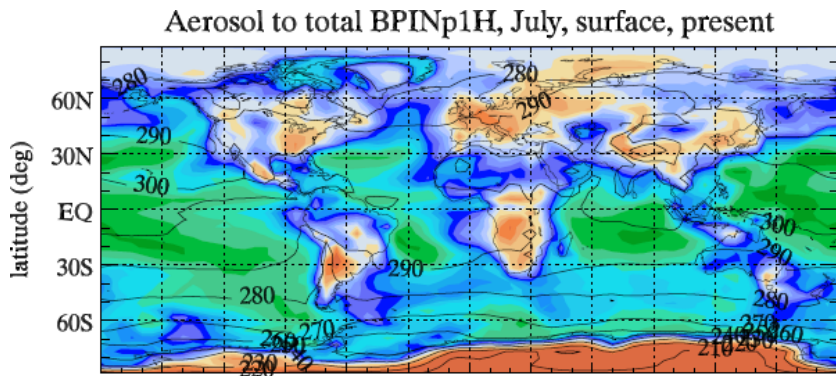

180W150W120W 90W 60W 30W 0E 30E 60E 90E 120E 150E 180E

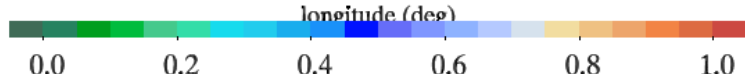

Aerosol to total BPINp2H, July, surface, present

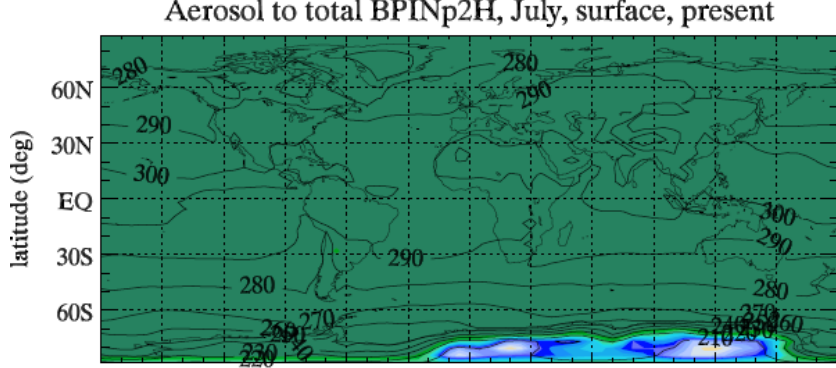

180W 150W120W 90W 60W 30W $0 \mathrm{E} \quad 30 \mathrm{E} \quad 60 \mathrm{E} \quad 90 \mathrm{E} \quad 120 \mathrm{E}$ 150E $180 \mathrm{E}$

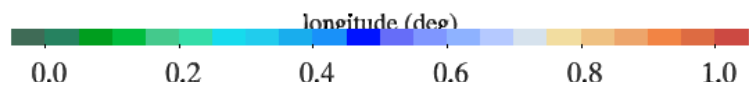

Aerosol to total BPINp1H, July, surface, present-preindustrial

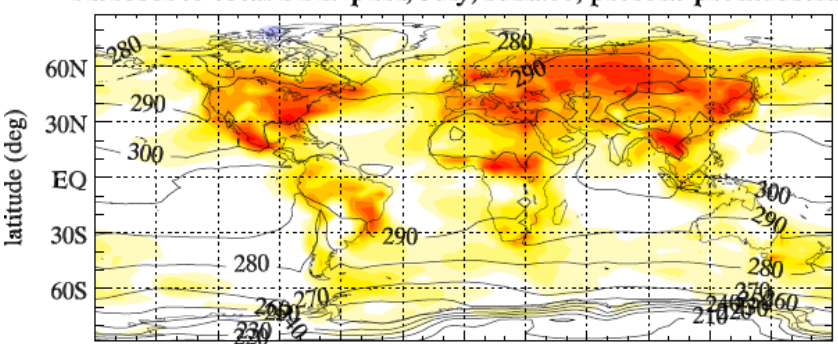

180W 150W 120W 90W 60W 30W 0E 30E 60E 90E 120E 150E 180E Innoitude (des)
$-0.60$
$-0.40$
$-0.20$
0.05
0.25
0.45

Aerosol to total BPINp2H, July, surface, present-preindustrial

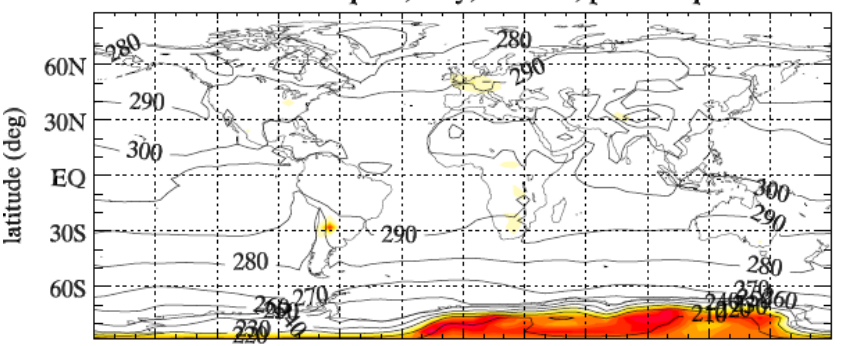

180W 150W 120W 90W 60W 30W 0E 30E 60E 90E 120E 150E $180 \mathrm{E}$ Ionoitude (deg)

$\begin{array}{llllll}-0.060 & -0.040 & -0.020 & 0.005 & 0.025 & 0.045\end{array}$

Fig. 6. Ratio of aerosol-phase to aerosol- and gas-phase SOA species (surface) for the present (left panels) and the corresponding difference from the preindustrial (right panels) simulation for BPINp1H (top panels) and BPINp2H (bottom panels). Contours show the monthly mean temperature $(\mathrm{K})$.

pronounced in the preindustrial period, when (excluding the South Pole) more than $90 \%$ of this species is in the gas phase. At the South Pole both BPINp1H and BPINp2H are found primarily in the aerosol phase due to the extremely low temperatures. North Pole temperatures are somewhat higher than at South Pole, and only the less volatile SOA species are dominantly in the aerosol-phase. There, temperature is the controlling factor. However, this is not the case in the other areas of the world, where the SOA species reside mostly in the aerosol phase mainly above land, and hardly above the oceans, even at locations with similar temperatures. This is because they tend to condense on pre-existing aerosols, which are more abundant above continental source regions. This land-sea difference is evidenced in both the preindustrial and present day simulations. The present day simulations show a more pronounced land-sea difference, due to the higher primary aerosol emissions.

\subsubsection{Zonal mean changes}

The zonal mean of the aerosol-phase to total mass ratios for the same two SOA species are shown in Fig. 7. Due to the very low temperatures in the upper troposphere/lower stratosphere (above $300 \mathrm{hPa}$ ) most $\mathrm{SOA}$ species reside in the aerosol phase. The most volatile species (BPINp2H) is mainly $(>50 \%)$ present in the gas-phase at temperatures above $240 \mathrm{~K}$, while the corresponding threshold temperature for the less volatile species is $285 \mathrm{~K}$. Thus, the more volatile species partition mainly in the gas-phase in the whole model domain except the cold area around the tropopause and in the lower stratosphere above South Pole, while the less volatile species are mostly present in the aerosol phase. Similar results are calculated for both the present and preindustrial atmospheres and indicate that, contrary to the surface, the partitioning of SOA species in the upper layers of the troposphere is temperature-driven. In addition, at very low temperatures, even for the very volatile species, the partitioning to the aerosol phase becomes very high, and forces almost all SOA material to reside in the aerosol phase. For the case of the less volatile BPINp1H, the difference in the partitioning at the surface discussed in Fig. 6 is also evident in Fig. 7.

It has to be mentioned once more that the present day atmosphere has more $\mathrm{NO}_{\mathrm{x}}$ than the preindustrial one, which causes different product yields of the parent VOC oxidation products (Presto et al., 2005; Song et al., 2005) and different product distribution, resulting in a further change in aerosol physical and optical properties. 

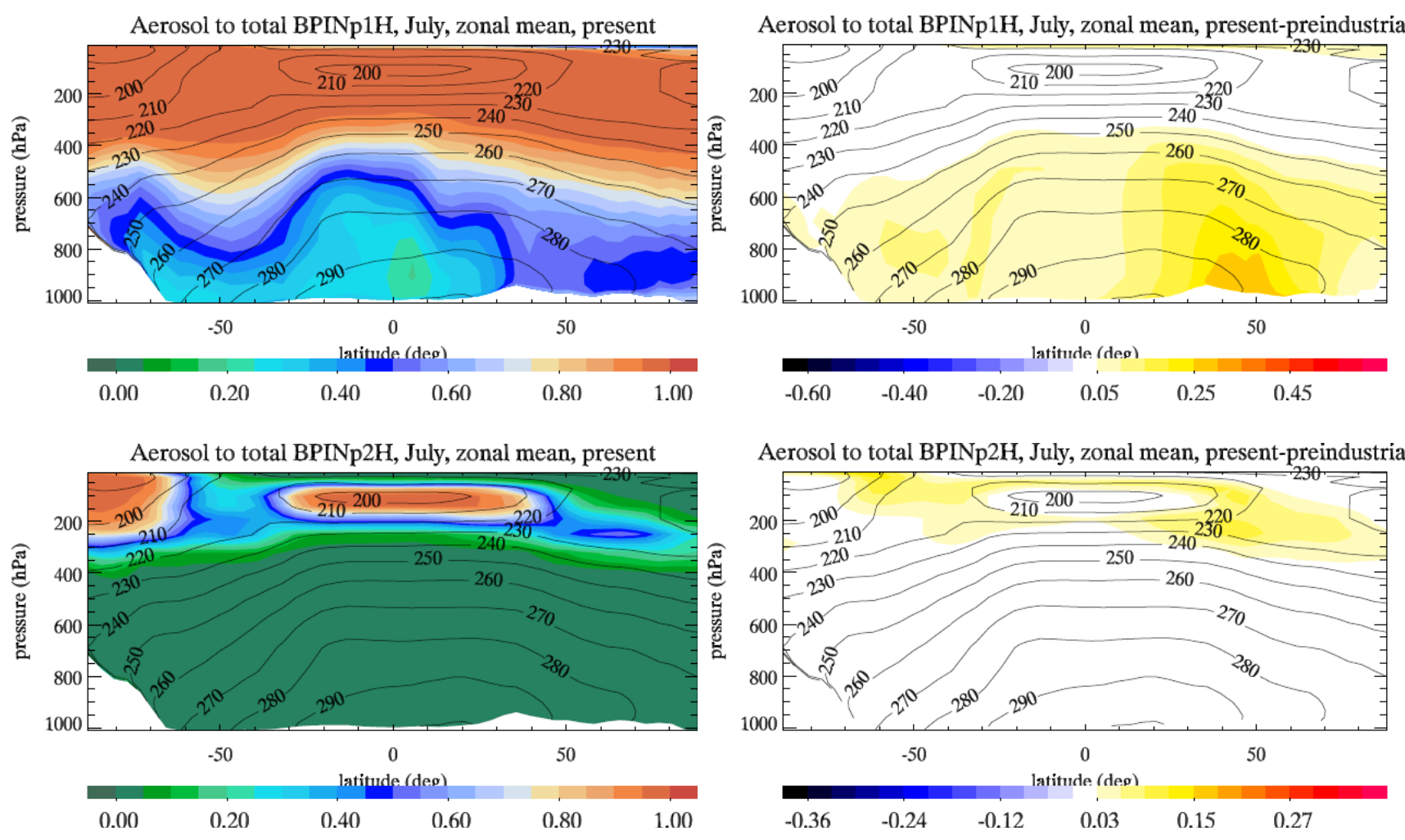

Fig. 7. Ratio of aerosol-phase to aerosol- and gas-phase SOA species (zonal mean) for the present (left panels) and the corresponding difference from the preindustrial (right panels) simulation for BPINp1H (top panels) and BPINp2H (bottom panels). Contours show the zonal mean temperature $(\mathrm{K})$. Note the different scale between the two panels on the right.

The chemical composition of SOA itself has also been modified, mainly due to the change in the preexisting aerosol mass. SOA produced from biogenic VOC contribute to about $90 \%$ to the total SOA in the present day (Tsigaridis and Kanakidou, 2003) and are mostly found in the troposphere. About $20 \%$ penetrates to the stratosphere (above $100 \mathrm{hPa}$ ) for the present day and $22 \%$ for the preindustrial simulation. These amounts are highly dependent on the way stratospheric-tropospheric exchanges are parameterized in the model, together with the temperature dependence on the partitioning coefficient of the SOA species. In the case of anthropogenically produced SOA (SOAa), only about $9 \%$ of their total burden is in the stratosphere. Regarding the tropospheric load of biogenic SOA, the model calculates that the boundary layer is enriched in SOAb since preindustrial times, since it contains nowadays $5.0 \%$ of the total SOAb burden compared to $3.8 \%$ in the past. This increase is attributed to the presence of more primary aerosol able to absorb the gas-phase SOAb species due to the enhanced emissions in the present day. Another important factor is the increase in tropospheric ozone that enhances the oxidation of the parent VOC to semi-volatile SOA precursor compounds in the lower atmosphere.

\subsubsection{Changes in biogenic SOA chemical composition}

In the present work we investigated changes in the relative contribution of the different SOAb species considered here that are driven from the temporal and spatial differences in temperature, oxidant levels and amount of pre-existing aerosol. Our model is able to provide information on the changes in the VOC oxidation product distribution due to the shift from high $\mathrm{VOC} / \mathrm{NO}_{\mathrm{x}}$ to low VOC/NOx environments. The change in the relative contribution of the individual SOAb species to the total SOAb mass in the boundary layer and in the free troposphere is displayed in Table 6. This relative contribution change is calculated by:

$\underline{\text { [present contribution (\%)]-[preindustrial contribution (\%)] }}$

$$
\text { [preindustrial contribution (\%)] }
$$

In the boundary layer, the significant increase in the primary aerosol mass favors the condensation of the most volatile SOAb species, such as BPINp2N, which has increased its relative contribution to the total SOAb mass (normalized, based on Eq. 3) by more than a factor of 4, while BPINp1N has doubled its relative contribution. The corresponding species that are being produced from the oxidation of $\beta$-pinene in high $\mathrm{VOC} / \mathrm{NO}_{\mathrm{x}}$ environments have decreased their relative contribution, due to the enrichment of $\mathrm{NO}_{\mathrm{x}}$ in the present 
Table 6. Relative contribution to the total biogenic SOA mass of the various SOA species at present day and corresponding relative change since preindustrial era, as calculated by Eq. (3).

\begin{tabular}{lllllll}
\hline & \multicolumn{2}{c}{ Boundary layer } & \multicolumn{2}{c}{ Free troposphere } & \multicolumn{2}{c}{ Stratosphere } \\
& Present & Change & Present & Change & Present & Change \\
\hline APINp1N & $4.2 \%$ & $249.2 \%$ & $0.5 \%$ & $144.4 \%$ & $0.2 \%$ & $115.4 \%$ \\
APINp2N & $30.6 \%$ & $397.0 \%$ & $20.4 \%$ & $111.1 \%$ & $13.8 \%$ & $94.5 \%$ \\
APINp1H & $36.2 \%$ & $-42.9 \%$ & $5.0 \%$ & $-41.7 \%$ & $2.2 \%$ & $-37.9 \%$ \\
APINp2H & $9.2 \%$ & $-35.5 \%$ & $8.9 \%$ & $-47.7 \%$ & $6.2 \%$ & $-47.6 \%$ \\
BPINp1N & $0.7 \%$ & $114.2 \%$ & $0.0 \%$ & $37.7 \%$ & $0.0 \%$ & $7.9 \%$ \\
BPINp2N & $12.7 \%$ & $430.8 \%$ & $51.3 \%$ & $32.7 \%$ & $61.7 \%$ & $28.3 \%$ \\
BPINp1H & $3.9 \%$ & $-51.7 \%$ & $0.2 \%$ & $-46.1 \%$ & $0.0 \%$ & $-37.8 \%$ \\
BPINp2H & $2.6 \%$ & $-39.6 \%$ & $13.7 \%$ & $-46.4 \%$ & $15.9 \%$ & $-45.8 \%$ \\
\hline
\end{tabular}
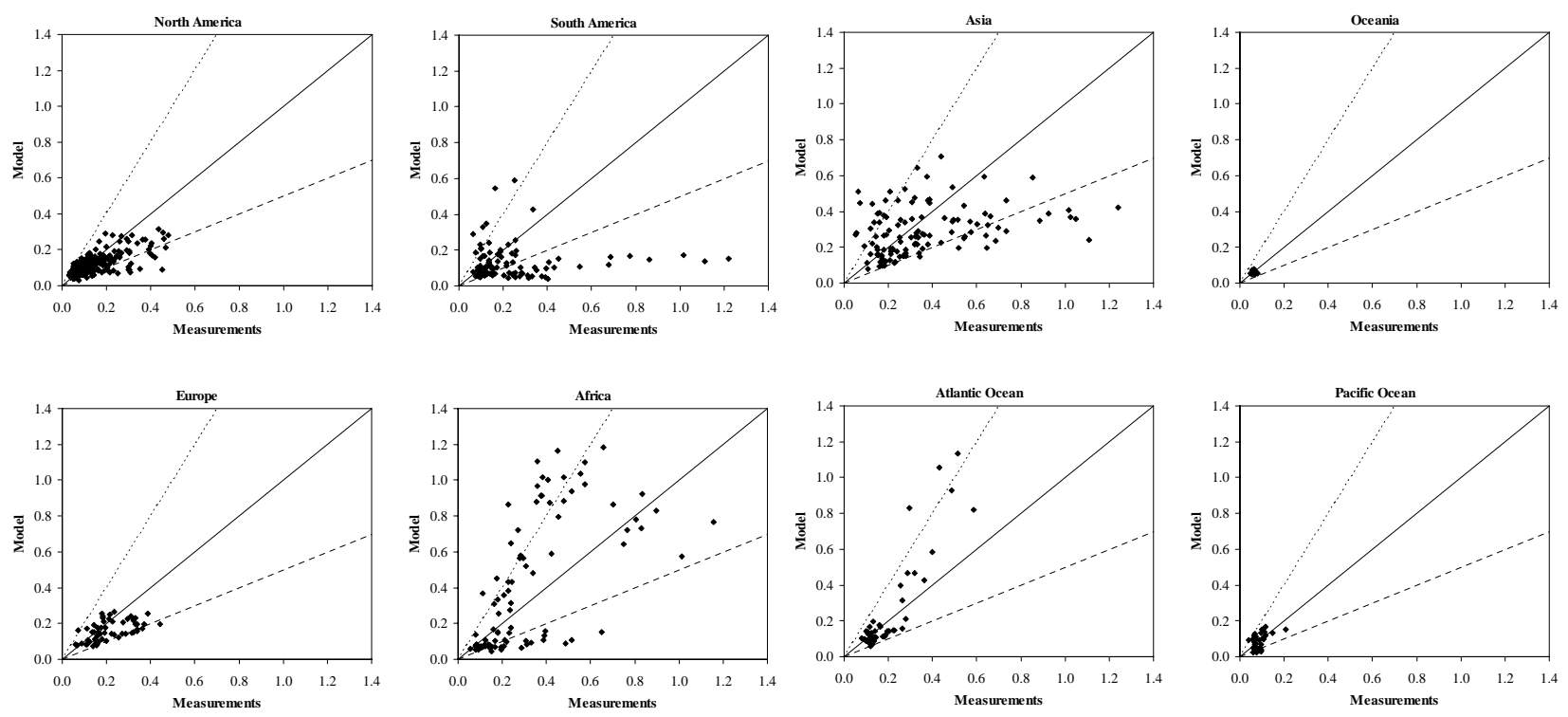

Fig. 8. AOD results vs. measurements (500nm) from the AERONET network (http://aeronet.gsfc.nasa.gov) separated by region. The solid line denotes the 1:1 ratio and the dotted lines the $1: 2$ and 2:1 ratios, respectively.

day atmosphere that makes their chemical formation pathway less favorable.

In the free troposphere, the medium-volatility SOAb species APINp1N and APINp2N, have more than doubled their relative contribution, while that of the other SOAb species has changed by less than 50\% on an annual basis. Like in the free troposphere, the species produced in low $\mathrm{VOC} / \mathrm{NO}_{\mathrm{x}}$ environments are favored against the ones produced in high $\mathrm{VOC} / \mathrm{NO}_{\mathrm{x}}$ environments due to the change in oxidant levels, which affects the product distribution of biogenic VOC oxidation.

\subsection{Aerosol optical depth}

AOD calculations are based on wet aerosol mass concentrations, size resolved specific extinction coefficients for seasalt are based on Shettle and Fenn (1979), for dust on Patterson (1981) and on Volz (1973), while for the rest of the aerosol components the specific extinction coefficients are shown in Table 7. The specific extinction coefficients are corrected for the effect of relative humidity as explained in Sect. 2.1. This has to be viewed as the upper limit for the water effect on aerosols and AOD, since hydrophilic carbonaceous aerosols are expected to be less hydrophilic than sulfate. The lower limit of this effect is calculated by the assumption that only sulfate and nitrate extinction coefficients are affected by water uptake. The resulting AOD is 
Table 7. Specific extinction coefficients used in the AOD calculations. Ammonium aerosol contribution is included to that of sulfate and nitrate.

\begin{tabular}{lll}
\hline Aerosol component & $B\left(\mathrm{~m}^{2} \mathrm{~g}^{-1}\right)$ & Reference \\
\hline $\mathrm{SO}_{4}^{=}$ & 5 & Jeuken et al. (2001) \\
$\mathrm{NO}_{3}^{-}$ & 5 & Jeuken et al. (2001) \\
$\mathrm{BC}$ & 9 & Liousse et al. (1996); Tegen et al. (1997) \\
$\mathrm{POA}$ & 4 & Liousse et al. (1996) \\
$\mathrm{SOA}$ & 4 & Liousse et al. (1996) \\
\hline
\end{tabular}

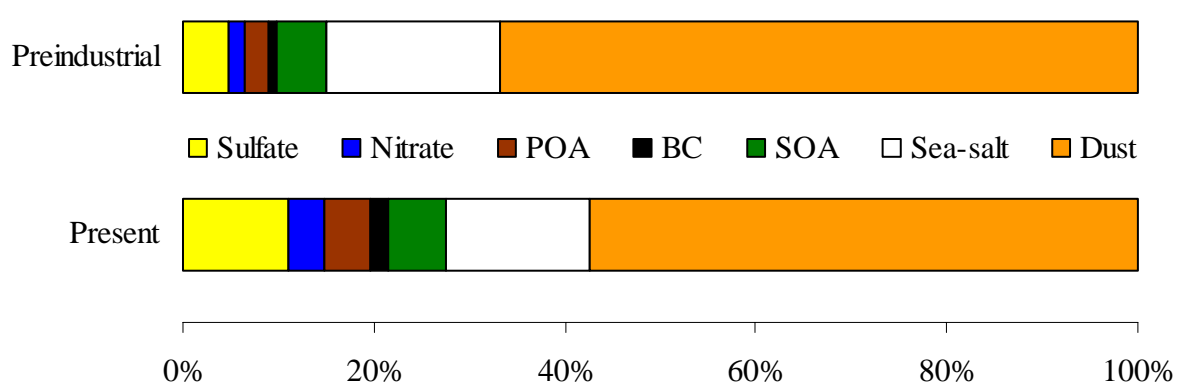

Fig. 9. Contribution to the total aerosol optical depth for each one of the aerosol species (annual global mean) for the preindustrial (top; AOD 0.084) and present (bottom; AOD 0.102) atmospheres. Ammonium aerosol is included in the nss-sulfate and nitrate contribution.

calculated to be $20 \%$ lower than the base case where all hydrophilic aerosols are treated like sulfate, pointing out that the error introduced by that assumption is lower than $20 \%$.

The global mean Aerosol Optical Depth (AOD) at $550 \mathrm{~nm}$ calculated by the model increased from 0.084 in the preindustrial atmosphere to 0.102 nowadays, a value smaller than the satellite measurements, mainly due to the underestimation of some aerosol components burden (Sect. 3.2). On average, the model tends to underestimate the AERONET network observations by about $10 \%$ (Fig. 8). There is a general trend on underestimating the AOD measurements, with the exception of Africa, where a general overestimation is calculated. The overestimation in the AOD calculations over Africa, mostly attributed to dust load, can explain the high global annual mean percent contribution of dust to the AOD (Fig. 9), for both the preindustrial and present atmospheres. The contribution of each species has changed since preindustrial times, with the most important change being the more than doubling of the nss-sulfate, nitrate, and BC contributions to the AOD, resulting from an increase of their sources and thus their atmospheric load. The POA contribution to the AOD has increased by $86 \%$. The increase in BC contribution by a factor of 2.7 is higher than that of POA due to BC lower solubility (reflected by the insoluble/soluble ratio in the emitted amounts compared to that of POA), which results in relatively less effective removal and thus higher burden (and higher AOD) compared to that of POA during the present day. Since sea-salt and dust have equal burdens during the present and preindustrial simulations, their rela- tive contribution to the total AOD has decreased nowadays by about $15 \%$ due to the increase of the other aerosol components. The SOA burden increases at the present day, but not so notably as the mainly anthropogenic aerosols. Therefore, SOA relative contribution to the total AOD is only $11 \%$ higher nowadays.

The percent contribution of the various components to the AOD per continent is shown in Fig. 10 both for the present and preindustrial atmospheres. As expected, the strongest changes have occurred over the most industrialized continents, namely North America, Europe and Asia. The anthropogenic emissions of $\mathrm{SO}_{2}$ and $\mathrm{NO}_{\mathrm{x}}$ have enhanced the nss-sulfate and nitrate aerosols, resulting in higher contribution to the AOD. In areas with strong deforestation, namely North and South America, Africa, and Indonesia - Oceania, the increase in the relative contribution of primary carbonaceous aerosols to the total AOD is also important.

\section{Conclusions}

The anthropogenic aerosol burden in the atmosphere has increased since preindustrial times by more than a factor of two for most anthropogenic aerosol species due to the increase in the emissions from human activities. In addition, the relative contribution of each one of the aerosol components has changed. Since preindustrial times black carbon, nss-sulfate and nitrate aerosols have increased their atmospheric load by a factor of 3.3, 2.6 and 2.7, respectively. This change is 

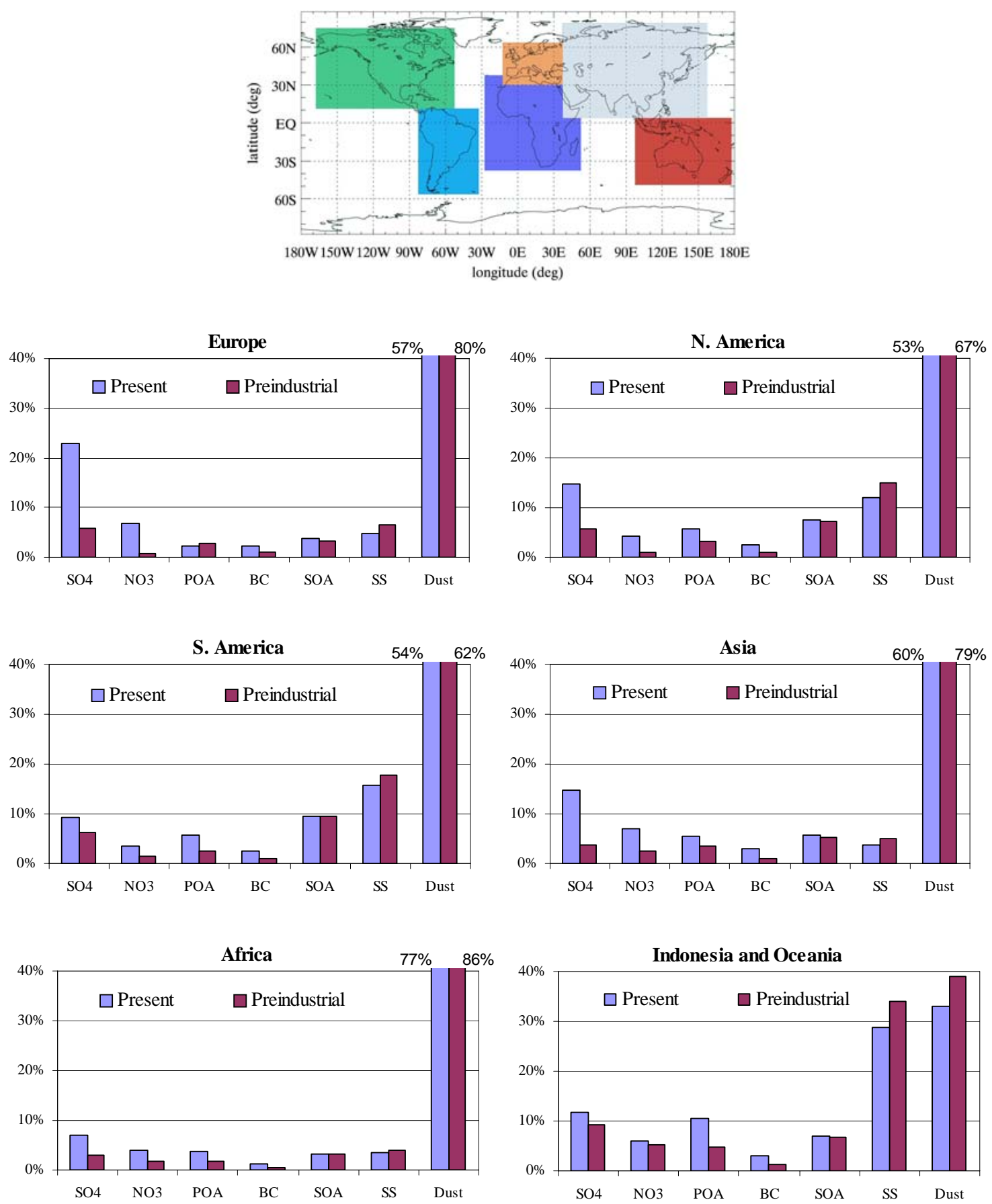

Fig. 10. Map: Continental box regions definition for the AOD comparison. The African box overlaps with the European and the Asian ones. Charts: Relative percentage contribution of aerosol components per continent for the present and preindustrial atmospheres. The effect of water is included to each one of the aerosol components. The continental mean AOD values for the present and preindustrial simulations respectively are: Europe: 0.204, 0.146; N. America: 0.092, 0.074; S. America: 0.099, 0.087; Asia: 0.179, 0.136; Africa: 0.311, 0.279; Indonesia and Oceania: 0.071, 0.060. SS means sea-salt.

accompanied by $34-42 \%$ faster conversion of hydrophobic to hydrophilic carbonaceous aerosol, attributed to the tropospheric $\mathrm{O}_{3}$ increase. Organic aerosols have increased their atmospheric load by $65 \%$. Due to the increase in inorganic salts, aerosol associated water has also increased. Interestingly, the increase in emissions of inorganic aerosol precursors $\mathrm{SO}_{2}, \mathrm{NH}_{3}$ and $\mathrm{NO}_{\mathrm{x}}$ since the preindustrial period of about a factor of 30,6 and 5, respectively, is much larger 
than the corresponding aerosol burden increase of nss-sulfate (factor of 2.6), ammonium (factor of 2.9) and nitrate (factor of 2.7), reflecting a non-linear atmospheric response.

Due to the change in the abundance of primary particles in the atmosphere, the semi-volatile species that form SOA condense to the aerosol phase easier at present time, increasing the boundary layer load of SOA to the total particulate mass faster than in the free troposphere and the lower stratosphere. The present-day added primary particles also favor the condensation of more volatile species in the boundary layer, at the expense of formation in the upper troposphere. In areas with high preexisting aerosol loads, the amount of aerosol is the most important parameter that controls whether the SOA species resides in the gas or the aerosol phase, while at low pre-existing aerosol concentrations the most important parameter is temperature. The first case is applicable close to the surface over continental areas while the second applies to the upper layers of the atmosphere and the South Pole. The most volatile SOA species tend to condense and accumulate in the upper layers of the troposphere where the temperatures are very low and removal is slow, while the non volatile species concentrate close to the surface since they are not able to reach the upper model layers, due to condensation on preexisting aerosol and subsequent removal by wet deposition. Additionally, due to the change in the atmospheric chemical composition, SOA species formed in low $\mathrm{VOC} / \mathrm{NO}_{\mathrm{x}}$ ratio regions contribute globally by $72 \%$ to the total SOA mass at present day compared to $48 \%$ during the preindustrial period $(50 \%$ and $7 \%$ in the boundary layer, respectively). This is important for aerosol properties, since the compounds present on SOA which are formed in different $\mathrm{VOC} / \mathrm{NO}_{\mathrm{x}}$ regions are expected to have different physicochemical characteristics, like solubility, hygrophilic/hygrophobic behavior, $\mathrm{CCN}$ activity etc, and thus different climatic impacts.

Significant regional changes in aerosol composition have occurred since preindustrial period, reflecting the industrialization in the north hemisphere and the intensive deforestation and biomass burning in the tropics. The changes in aerosol composition alter the water associated to aerosols together with their physicochemical and optical properties, which will in turn affect the condensation nuclei and cloud condensation nuclei properties of aerosols themselves. Particles have become more hydrophilic and their chemical composition change has altered their potential impact on climate. This involves both the direct effect, due to changes in the optical properties of aerosols, and the indirect effect, due to changes in the cloud properties and precipitation rates. To evaluate these changes additional knowledge is needed on the hygroscopic and optical properties of mixed atmospheric aerosols and their interactions with gaseous compounds.

If we account for all carbonaceous and inorganic aerosols and the aerosol associated water, the aerosol optical depth (AOD) has increased by $21 \%$ since preindustrial times. Black carbon and primary organic carbon have increased their contribution to the total AOD by a factor of 2.7 and 1.9 , respectively, nss-sulfate by a factor of 2.2 , nitrate by a factor of 2.4 while the SOA contribution has increased by $11 \%$. Excluding dust and sea-salt, sulfate has the highest AOD contribution in both simulations except the preindustrial second half of the year (July to December) when SOA dominates. We assume that dust and sea-salt loads have not changed since preindustrial times, but due to the increase of other aerosol constituents their contribution to the AOD is about $15 \%$ lower.

Acknowledgements. This work has been supported by European Social Funds and Greek National Resources EPEAEK II PYTHAGORAS grant.

Edited by: U. Lohmann

\section{References}

Adams, P. J., Seinfeld, J. H., Koch, D., Mickley, L., and Jacob, D.: General circulation model assessment of direct radiative forcing by the sulfate-nitrate-ammonium-water inorganic aerosol system, J. Geophys. Res., 106, 1097-1111, 2001.

Anfossi, D., Sandroni, S., and Viarengo, S.: Tropospheric ozone in the nineteenth century: the Moncalieri series, J. Geophys. Res., 96, 17349-17353, 1991.

Barth, M. C., Rasch, P. J., Kiehl, J. T., Benkovitz, C. M., and Schwartz, S. E.: Sulfur chemistry in the National Center for Atmospheric Research Community Climate Model: Description, evaluation, features, and sensitivity to aqueous chemistry, J. Geophys. Res., 105, 1387-1415, 2000.

Boucher, O. and Pham, M.: History of sulfate aerosol radiative forcings, Geophys. Res. Lett., 29, 1308, doi:10.1029/2001GL014048, 2002.

Chin, M., Rood, R. B., Lin, S.-J., Müller, J.-F., and Thompson, A. M.: Atmospheric sulfur cycle simulated in the global model GOCART: Model description and global properties, J. Geophys. Res., 105, 24 671-24 687, 2000.

Chuang, C. C., Penner, J. E., Prospero, J. M., Grant, K. E., Rau, G. H., and Kawamoto, K.: Cloud susceptibility and the first aerosol indirect forcing: sensitivity to black carbon and aerosol concentrations, J. Geophys. Res., 107, 4564, doi:10.1029/2000JD000215, 2002.

Chung, S. and Seinfeld, J. H.: Global distribution and climate forcing of carbonaceous aerosols, J. Geophys. Res., 107, 4407, doi:10.1029/2001JD001397, 2002.

Claeys, M., Wang, W., Ion, A. C., Kourtchev, I., Gelencsér, A., and Maenhaut, W.: Formation of secondary organic aerosols from isoprene and its gas-phase oxidation products through reaction with hydrogen peroxide, Atmos. Environ., 38, 4093-4098, 2004.

Cooke, W. F. and Wilson, J. J. N.: A global black carbon aerosol model, J. Geophys. Res., 101, 19395-19409, 1996.

Dentener, F. J., Feichter, J., and Jeuken, A.: Simulation of the transport of $\mathrm{Rn}^{222}$ using on-line and off-line global models at different horizontal resolutions: a detailed comparison with measurements, Tellus, 51B, 573-602, 1999.

Dentener, F., Kinne, S., Bond, T., Boucher, O., Cofala, J., Generoso, S., Ginoux, P., Gong, S., Hoelzemann, J. J., Ito, A., Marelli, L., 
Penner, J. E., Putaud, J.-P., Textor, C., Schulz, M., van der Werf, G. R., and Wilson, J.: Emissions of primary aerosol and precursor gases in the years 2000 and 1750, prescribed data-sets for AeroCom, Atmos. Chem. Phys., 6, 4321-4344, 2006, http://www.atmos-chem-phys.net/6/4321/2006/.

Derwent, R. G., Collins, W. J., Jenkin, M. E., Johnson, C. E., and Stevenson, D. S.: The global distribution of secondary particulate matter in a 3-D lagrangian chemistry transport model, J. Atmos. Chem., 44, 57-95, 2003.

Gery, M. W., Whitten, G. Z., Killus, J. P., and Dodge, M. C.: A photochemical kinetics mechanism for urban and regional scale computer modeling. J. Geophys. Res., 94, 12 925-12 956, 1989.

Gibson, R., Kallberg, P., and Uppala, S.: The ECMWF re-analysis (ERA) project, ECMWF newsletter, 73, 7-17, 1997.

Ginoux, P., Chin, M., Tegen, I., Prospero, J. M., Holben, B., Dubovik, O., and Lin. S.-J.: Sources and distributions of dust aerosols simulated by the GOCART model, J. Geophys. Res., 106, 20 255-20 273, 2001.

Griffin, R. J., Cocker III, D. R., Flagan, R. C., and Seinfeld, J. H.: Organic aerosol formation from oxidation of biogenic hydrocarbons, J. Geophys. Res., 104, 3555-3567, 1999a.

Griffin, R. J., Cocker, D. R., Seinfeld, J. H., and Dabdub, D.: Estimate of global atmospheric aerosol from oxidation of biogenic hydrocarbons, Geophys. Res. Lett., 26, 2721-2724, 1999b.

Grini, A., Myhre, G., Zender, C. S., and Isaksen, I. S. A.: Model simulations of dust sources and transport in the global atmosphere: effects of soil erodibility and wind speed variability, J. Geophys. Res., 110, D02205, doi:10.1029/2004JD005037, 2005.

Guelle, W., Schulz, M., Balkanski, Y., and Dentener, F. J.: Influence of the source formulation on modeling the atmospheric global distribution of sea salt aerosol, J. Geophys. Res., 106, 27 50927 524, 2001.

Haan, D. and Raynaud, D.: Ice core record of CO variations during the last two millennia: atmospheric implications and chemical interactions within the Greenland ice, Tellus, 50B, 253-262, 1998.

Haan, D., Martinerie, P., and Raynaud, D.: Ice core data of atmospheric carbon monoxide over Antarctica and Greenland during the last 200 years, Geophys. Res. Lett., 23, 2235-2238, 1996.

Hauglustaine, D. A. and Brasseur, G. P.: Evolution of tropospheric ozone under anthropogenic activities and associated radiative forcing of climate, J. Geophys. Res., 106, 32 337-32 360, 2001.

Heald, C. L., Jacob, D. J., Park, R. J., Russell, L. M., Huebert, B. J., Seinfeld, J. H., Liao, H., and Weber, R. J.: A large organic aerosol source in the free troposphere missing from current models, Geophys. Res. Lett., 32, L18889, doi:10.1029/2005GL023831, 2005.

Hegg, D. A., Livingston, J., Hobbs, P. V., Novakov, T., and Russell, P.: Chemical apportionment of aerosol column optical depth off the mid-Adlantic coast of the United States, J. Geophys. Res., 102, 25 293-25 303, 1997.

Hein, R., Crutzen, P. J., and Heimann, M.: An inverse modeling approach to investigate the global atmospheric methane cycle, Global Biogeochem. Cycles, 11, 43-76, 1997.

Henze, D. K. and Seinfeld, J. H.: Global secondary organic aerosol from isoprene oxidation, Geophys. Res. Lett., 33, L09812, doi:10.1029/2006GL025976, 2006.

Hoffmann, T., Odum, J. R., Bowman, F., Collins, D., Klockow, D., Flagan, R. C., and Seinfeld, J. H.: Formation of organic aerosols from the oxidation of biogenic hydrocarbons, J. Atmos. Chem., 26, 189-222, 1997.

Houweling, S., Dentener, F., and Lelieveld, J.: The impact of nonmethane hydrocarbon compounds on tropospheric chemistry, J. Geophys. Res., 103, 10 673-10 696, 1998.

Huebert, B., Bertram, T., Kline, J., Howell, S., Eatough, D., and Blomquist, B.: Measurements of organic and elemental carbon in Asian outflow during ACE-Asia from the NSF/NCAR C-130, J. Geophys. Res., 109, D19S11, doi:10.1029/2004JD004700, 2004.

Intergovernmental Panel on Climate Change (IPCC): Climate change: the scientific basis, Cambridge University Press, UK, 2001.

Ito, A. and Penner, J. E.: Historical emissions of carbonaceous aerosols from biomass and fossil fuel burning for the period 1870-2000, Global Biogeochem. Cycles, 19, GB2028, doi:10.1029/2004GB002374, 2005.

Jaenicke, R.: Abundance of cellular material and proteins in the atmosphere, Science, 308, 73, 2005.

Jeuken, A., Veefkind, J. P., Dentener, F., Metzger, S., and Gonzalez, C. R.: Simulation of the aerosol optical depth over Europe for August 1997 and a comparison with observations, J. Geophys. Res. 106, 28 295-28311, 2001.

Kanakidou, M., Seinfeld, J. H., Pandis, S. N., Barnes, I., Dentener, F. J., Facchini, M. C., van Dingenen, R., Ervens, B., Nenes, A., Nielsen, C. J., Swietlicki, E., Putaud, J. P., Balkanski, Y., Fuzzi, S., Horth, J., Moortgat, G. K., Winterhalter, R., Myhre, C. E. L., Tsigaridis, K., Vignati, E., Stephanou, E. G., and Wilson, J.: Organic aerosols and global climate modeling: a review, Atmos. Chem. Phys., 5, 1053-1123, 2005a.

Kanakidou, M., Tsigaridis, K., Kalivitis, N., Balis, D., Dentener, F. J., Martins Dos Santos, S., Vignati, E., Wilson, J., Putaud, J.P., van Dingenen, R., Raes, F., Feichter, J., Kinne, S., Stier, P., Kloster, S., Quaas J., Lawrence, M., Lelieveld, J., Metzger, S., Lang, R., Gazenveld, L., Salzmann, M., Schulz, M., Balkanski, Y., Textor, C., Guibert, S., Boucher, O., Reddy, S., Roelofs, G.-J., Krol, M., Jongen, S., Facchini, M.-C., and Mircea, M.: PHOENICS (Particles of Human Origin Extinguish Natural solar Irradiance in the Climate System) synthesis and integration report, edited by: Kanakidou, M. and Dentener, F. J., Emedia University of Crete, Heraklion, Greece, ISBN 960-88712-0-4, 2005 b.

Kanakidou, M., Tsigaridis, K., Dentener, F. J., and Crutzen, P. J.: Human-activity-enhanced formation of organic aerosols by biogenic hydrocarbon oxidation, J. Geophys. Res., 105, 9243-9254, 2000.

Kettle, A. J., Andreae, M. O., Amouroux, D., Andreae, T. W., Bates, T. S., Berresheim, H., Bingemer, H., Boniforti, R., Curran, M. A. J., DiTullio, G. R., Helas, G., Jones, G. B., Keller, M. D., Kiene, R. P., Leck, C., Levasseur, M., Malin, G., Maspero, M., Matrai, P., McTaggart, A. R., Mihalopoulos, N., Nguyen, B. C., Novo, A., Putaud, J. P., Rapsomanikis, S., Roberts, G., Schebeske, G., Sharma, S., Simó, R., Staubes, R., Turner, S., and Uher, G: A global database of sea surface dimethyl sulfide (DMS) measurements and a procedure to predict sea surface DMS as a function of latitude, longitude, and month, Global Biogeochem. Cycles, 13, 399-444, 1999.

Kiehl, J. T., Schneider, T. L., Rasch, P. J., Barth, M. C., and Wong, J.: Radiative forcing due to sulphate aerosols from simulations with the National Center for Atmospheric Research Community 
Climate Model, Version 3, J. Geophys. Res., 105, 1441-1457, 2000 .

Kirkevåg, A. and Iversen, T.: Global direct radiative forcing by process-parameterized aerosol optical properties, J. Geophys. Res., 107, 4433, doi:10.1029/2001JD000886, 2002.

Koch, D., Park, J., and del Genio, A.: Clouds and sulfate are anticorrelated: A new diagnostic for global sulphur models, J. Geophys. Res., 108, 4781, doi:10.1029/2003JD003621, 2003.

Koch, D.: Transport and direct radiative forcing of carbonaceous and sulfate aerosols in the GISS GCM, J. Geophys. Res., 106, 20311-20332, 2001.

Lathière, J., Hauglustaine, D. A., Friend, A., De Noblet-Ducoudré, N., Viovy, N., and Folberth, G.: Impact of climate variability and land use changes on global biogenic volatile organic compound emissions, Atmos. Chem. Phys., 6, 2129-2146, 2006, http://www.atmos-chem-phys.net/6/2129/2006/.

Lathière, J., Hauglustaine, D. A., De Noblet-Ducoudré, N., Krinner, G., and Folberth, G. A.: Past and future changes in biogenic volatile organic compound emissions simulated with a global dynamic vegetation model, Geophys. Res. Lett., 32, L20818, doi:10.1029/2005GL024164, 2005.

Lelieveld, J. and Dentener, F. J.: What controls tropospheric ozone?, J. Geophys. Res., 105, 3531-3551, 2000.

Liao, H., Seinfeld, J. H., Adams, P. J., and Mickley, L. T.: Global radiative forcing of coupled tropospheric ozone and aerosols in a unified general circulation model, J. Geophys. Res., 109, D16207, doi:10.1029/2003JD004456, 2004.

Liousse, C., Penner, J. E., Chuang, C., Walton, J. J., Eddleman, H., and Cachier, H.: A global three-dimensional model study of carbonaceous aerosols, J. Geophys. Res., 101, 19411-19432, 1996.

Luo, C., Mahowald, N. M., and del Corral, J.: Sensitivity study of meteorological parameters on mineral aerosol mobilization, transport, and distribution, J. Geophys. Res., 108, 4447, doi:10.1029/2003JD003483, 2003.

Marenco, A., Gouget, H., Nédélec, P., Pagès, J.-P., and Karcher, F.: Evidence of a long-term increase in tropospheric ozone from Pic du Midi data series: concequences - positive radiative forcing, J. Geophys. Res., 99, 16617-16 632, 1994.

Mayewski, P. A., Lyons, W. B., Spencer, M. J., Twickler, M., Dansgaard, W., Koci, B., Davidson, C. I., and Honrath, R. E.: Sulfate and nitrate concentrations from a south Greenland ice core, Science, 232, 975-977, 1986.

Menon, S., Del Genio, A. D., Koch, D., and Tselioudis, G.: GCM simulations on the aerosol indirect effect: sensitivity to cloud parameterization and aerosol burden, J. Atmos. Sci., 59, 692713, 2002.

Metzger, S., Dentener, F., Pandis, S. N., and Lelieveld, J.: Gas/aerosol partitioning: 1. A computationally efficient model, J. Geophys. Res., 107, doi:10.1029/2001JD001102, 2002.

Miller, R. L., Tegen, I., and Perlwitz, J.: Surface radiative forcing by soil dust aerosols and the hydrologic cycle, J. Geophys. Res., 109, D04203, doi:10.1029/2003JD004085, 2004.

O’Dowd, C. D., Facchini, M. C., Cavalli, F., Ceburnis, D., Mircea, M., Decesari, S., Fuzzi, S., Yoon, Y. J., and Putaud, J.-F.: Biogenically driven organic contribution to marine aerosol, Nature, 431, 676-680, 2004.

Odum, J. R., Jungkamp, T. P. W., Griffin, R. J., Flagan, R. C., and Seinfeld, J. H.: The atmospheric aerosol-forming potential of whole gasoline vapor, Science, 276, 96-99, 1997.

Patterson, E. M.: Optical properties of the crystal aerosol - relation to chemical and physical characteristics, J. Geophys. Res., 86, 3236-3246, 1981.

Pavelin, E. G., Johnson, C. E., Rughooputh, S., and Toumi, R.: Evaluation of preindustrial ozone measurements made using Schönbein's method, Atmos. Environ., 33, 919-929, 1999.

Presto, A. A., Huff Hartz, K. E., and Donahue, N. M.: Secondary organic aerosol production from terpene ozonolysis. 2. Effect of $\mathrm{NO}_{\mathrm{x}}$ concentration, Environ. Sci. Technol., 39, 7046-7054, 2005.

Putaud, J. P., Raes, F., Van Dingenen, R., Brüggemann, E., Facchini, M. C., Decesari, S., Fuzzi, S., Gehrig, R., Hüglin, C., Laj, P., Lorbeer, G., Maenhaut, W., Mihalopoulos, N., Müller, K., Querol, X., Rodriguez, S., Schneider, J., Spindler, G., ten Brink, H., Tørseth, K., and Wiedensohler, A.: A European aerosol phenomenology 2: chemical characteristics of particulate matter at kerbside, urban, rural and background sites in Europe, Atmos. Environ., 38, 2579-2595, 2004.

Rasch, P. J., Barth, M. C., Kiehl, J. T., Schwartz, S. E., and Benkovitz, C. M.: A description of the global sulfur cycle and its controlling processes in the National Center for Atmospheric Research Community Climate Model, Version 3, J. Geophys. Res., 105, 1367-1385, 2000.

Reddy, M. S. and Boucher, O.: A study of the global cycle of carbonaceous aerosols in the LMDZT general circulation model, J. Geophys. Res., 109, D14202, doi:10.1029/2003JD004048, 2004.

Rotstayn, L. D. and Lohmann, U.: Simulation of the tropospheric sulfur cycle in a global model with a physically based cloud scheme, J. Geophys. Res., 107, 4592, doi:10.1029/2002JD002128, 2002.

Sandroni, S. and Alfonsi, D.: Historical data of surface ozone at tropical latitudes, Sci. Total Environ., 148, 23-29, 1994.

Sandroni, S., Alfonsi, D., and Viarengo, S.: Surface ozone levels at the end of nineteenth century in South America, J. Geophys. Res., 97, 2535-2539, 1992.

Seinfeld, J. H. and Pandis, S. N.: Atmospheric chemistry and physics: from air pollution to climate change, John Wiley, New York, 1998.

Shettle, E. P. and Fenn, R. W.: Models for the aerosols of the lower atmosphere and the effects of humidity variations on their optical properties, AFGL-TR-79-0214, Environmental Research Paper No. 675, NTIS, ADA 085851, 94 pp.

Shindell, D. T. and Faluvegi, G.: An exploration of ozone changes and their radiative forcing prior to the chlorofluorocarbon era, Atmos. Chem. Phys., 2, 363-374, 2002,

http://www.atmos-chem-phys.net/2/363/2002/.

Sigg, A. and Neftel, A.: Evidence for a 50\% increase in $\mathrm{H}_{2} \mathrm{O}_{2}$ over the past 200 years from a Greenland ice core, Nature, 351, 557$559,1991$.

Song, C., Na, K., and Cocker III, D. R.: Impact of hydrocarbon to $\mathrm{NO}_{\mathrm{x}}$ ratio on secondary organic aerosol formation, Environ. Sci. Technol., 39, 3143-3149, 2005.

Stier, P., Feichter, J., Kinne, S., Kloster, S., Vignati, E., Wilson, J., Ganzeveld, L., Tegen, I., Werner, M., Balkanski, Y., Schultz, M., Boucher, O., Minikin, A., and Petzold, A.: The aerosolclimate model ECHAM-HAM, Atmos. Chem. Phys., 5, 11251156, 2005, http://www.atmos-chem-phys.net/5/1125/2005/. 
Stier, P., Feichter, J., Roeckner, E., Kloster, S., and Esch, M.: The evolution of the global aerosol system in a transient climate simulation from 1860 to 2100, Atmos. Chem. Phys., 6, 3059-3076, 2006 , http://www.atmos-chem-phys.net/6/3059/2006/.

Textor, C., Schulz, M., Guibert, S., Kinne, S., Balkanski, Y., Bauer, S., Berntsen, T., Berglen, T., Boucher, O., Chin, M., Dentener, F. J., Diehl, T., Easter, R., Feichter, H., Fillmore, D., Ghan, S., Ginoux, P., Gong, S., Grini, A., Hendricks, J., Horowitz, L., Huang, P., Isaksen, I. S. A., Iversen, T., Kloster, S., Koch, D., Kirkevåg, A., Kristjansson, J. E., Krol, M., Lauer, A., Lamarque, J.-F., Liu, X., Montanaro, V., Myhre, G., Penner, J., Pitari, G., Reddy, S., Seland, Ø, Stier, P., Takemura, T., and Tie, X.: Analysis and quantification of the diversities of aerosol life cycles within AeroCom, Atmos. Chem. Phys., 6, 1777-1813, 2006, http://www.atmos-chem-phys.net/6/1777/2006/.

Tegen, I., Hollrig, P., Chin, M., Fung, I., Jacob, D., and Penner, J.: Contribution of different aerosol species to the global aerosol extinction optical thickness: Estimates from model results, J. Geophys. Res., 102, 23 895-23 915, 1997.

Tie, X., Madronich, S., Walters, S., Edwards, D. P., Ginoux, P., Mahowald, N., Zhang, R. Y., Lou, C., and Brasseur, G.: Assessment of the global impact of aerosols on tropospheric oxidants, J. Geophys. Res., 110, D03204, doi:10.1029/2004JD005359, 2005.

Tsigaridis, K. and Kanakidou, M.: Global modelling of secondary organic aerosol in the troposphere: A sensitivity analysis, Atmos. Chem. Phys., 3, 1849-1869, 2003, http://www.atmos-chem-phys.net/3/1849/2003/.
Tsigaridis, K., Lathière, J., Kanakidou, M., and Hauglustaine, D. A.: Naturally driven variability in the global secondary organic aerosol over a decade, Atmos. Chem. Phys., 5, 1891-1904, 2005, http://www.atmos-chem-phys.net/5/1891/2005/.

Van Aardenne, J. A., Dentener, F. J., Olivier, J. G. J., Klein Goldewijk, C. G. M., and Lelieveld, J.: A $1^{\circ} \times 1^{\circ}$ resolution data set of historical anthropogenic trace gas emissions for the period 18901990, Global Biogeochem. Cycles, 15, 909-928, 2001.

Veefkind, P.: Aerosol satellite remote sensing, PhD Thesis, Utrecht University, The Netherlands, 1999.

Volz, A. and Kley, D.: Evaluation of the Montsouris series ozone measurements made in the nineteenth sentury, Nature, 332, 240242, 1988.

Volz, F. E.: Infrared optical-constants of ammonium sulfate, sahara dust, volcanic pumice, and flyash, Appl. Opt., 12, 564-568, 1973.

Wang, Y. and Jacob, D. J.: Anthropogenic forcing on tropospheric ozone and $\mathrm{OH}$ since preindustrial times, J. Geophys. Res., 103, 31 123-31 135, 1998.

Zender, C. S., Bian, H., and Newman, D.: Mineral Dust Entrainment and Deposition (DEAD) model: Description and 1990s dust climatology, J. Geophys. Res., 108, 4416, doi:10.1029/2002JD002775, 2003. 